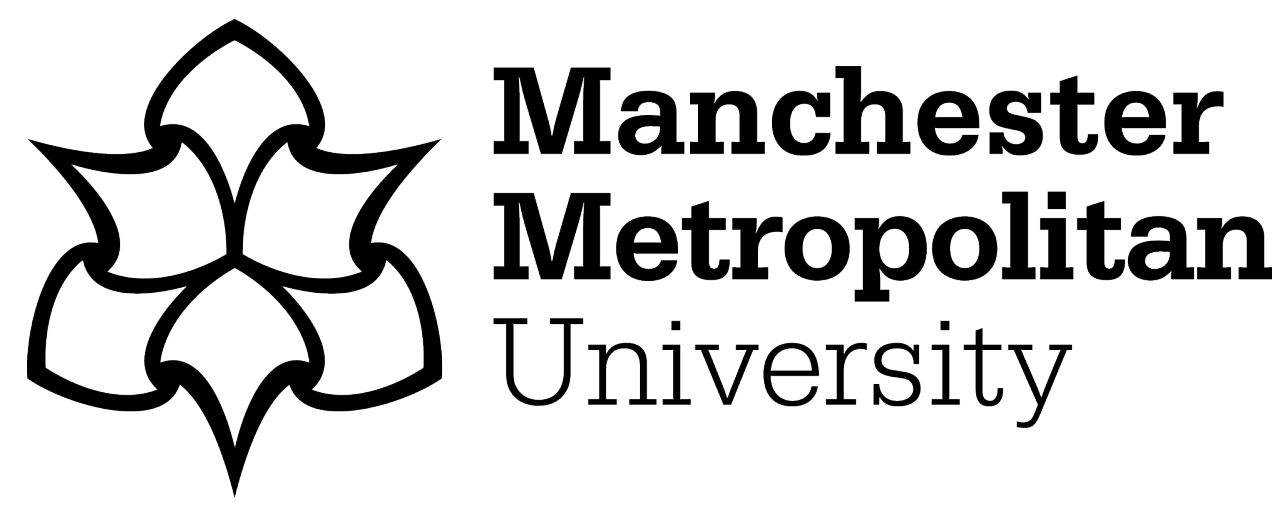

Adamson, Kathryn, Lane, Timothy, Carney, Matthew, Bishop, Thomas and Delaney, Catherine (2019) High-resolution proglacial lake records of preLittle Ice Age glacier advance, northeast Greenland. Boreas, 48 (3). pp. 535-550. ISSN 0300-9483

Downloaded from: https://e-space.mmu.ac.uk/622059/

Version: Accepted Version

Publisher: Wiley

DOI: https://doi.org/10.1111/bor.12361

Please cite the published version 


\title{
High-resolution proglacial lake records of pre-Little Ice Age glacier advance, northeast Greenland
}

\author{
KATHRYN ADAMSON ID, TIMOTHY LANE, MATTHEW CARNEY, THOMAS BISHOP AND CATHY DELANEY
}

\begin{abstract}
Adamson, K., Lane, T., Carney, M., Bishop, T. \& Delaney, C.: High-resolution proglacial lake records of pre-Little Ice Age glacier advance, northeast Greenland. Boreas. https://doi.org/10.1111/bor.12361. ISSN 0300-9483.

Understanding Arctic glacier sensitivity is key to predicting future response to air temperature rise. Previous studies have used proglacial lake sediment records to reconstruct Holocene glacier advance-retreat patterns in South and West Greenland, but high-resolution glacier records from High Arctic Greenland are scarce, despite the sensitivity of this region to future climate change. Detailed geochemical analysis of proglacial lake sediments close to Zackenberg, northeast Greenland, provides the first high-resolution record of Late Holocene High Arctic glacier behaviour. Three phases of glacier advance have occurred in the last 2000 years. The first two phases (c. 1320-800 cal. a BP) occurred prior to the Little Ice Age (LIA), and correspond to the Dark Ages Cold Period and the Medieval Climate Anomaly. The third phase (c. 700 cal. a BP), representing a smaller scale glacier oscillation, is associated with the onset of the LIA. Our results are consistent with recent evidence of pre-LIA glacier advance in other parts of the Arctic, including South and West Greenland, Svalbard, and Canada. The sub-millennial glacier fluctuations identified in the Madsen Lake succession are not preserved in the moraine record. Importantly, coupled XRF and XRD analysis has effectively identified a phase of ice advance that is not visible by sedimentology alone. This highlights the value of high-resolution geochemical analysis of lake sediments to establish rapid glacier advance-retreat patterns in regions where chronological and morphostratigraphical control is limited.
\end{abstract}

Kathryn Adamson (k.adamson@mmu.ac.uk), Matthew Carney and Cathy Delaney, School of Science and the Environment, Manchester Metropolitan University, Manchester M1 5GD, UK; Timothy Lane, School of Natural Sciences and Psychology, Liverpool John Moores University, Liverpool L3 3AF, UK; Thomas Bishop, Department of Geography, The University of Manchester, Manchester M13 9PL, UK, received 25th March 2018, accepted 9th October 2018 .

Unprecedented Arctic air temperature rise is causing profound retreat of the Greenland Ice Sheet (GrIS) and its surrounding glaciers and ice cap(s) (GICs). Recent mapping has shown that GICs cover $90000 \mathrm{~km}^{2}$, an area $50 \%$ larger than previously estimated (Rastner et al. 2012). Although this represents only 5\% of Greenland's glaciated area (Wouters et al. 2017), it accounts for 15$20 \%$ of Greenland's eustatic sea-level rise contribution $\left(\sim 0.05-1.10 \mathrm{~mm} \mathrm{a}^{-1}\right.$ from 2003 to 2008 , Bolch et al. 2013). The small size of these ice masses means that they are more sensitive to climate change than the GrIS (Machguth et al. 2013). This is especially significant in the High Arctic (north of the $+6{ }^{\circ} \mathrm{C}$ July isotherm; Bliss 1997), which is expected to experience some of the most intense changes in response to climate warming by the end of the century, including enhanced glacier melt and increased precipitation (Lund et al. 2017). These changes are expected to be spatially and temporally nonuniform (Carr et al. 2013; Moon et al. 2014), so understanding the rate and pattern of sub-centennial glacier behaviour is important to reliably predict future changes.

Of the 20 available mass balance records from GICs, multidecadal measurements are scarce. Where they do exist (see Machguth et al. 2016 for locations), they rarely extend to the present day or are not annually resolved. One record, from the Nuusuaq glaciers in West Greenland (1892-1993) spans 101 years, and data from Mittivakkat, southeast Greenland, spans 20 years (1996present). In northeast Greenland, two detailed records exist (2008-present) at A. P. Olsen ice cap and Freya glacier, close to Zackenberg (Machguth et al. 2013, 2016), but these do not yet provide multidecadal archives. In some locations, such as southeast Greenland, air photographs have been valuable in examining decadal changes in glacier fluctuations (Bjørk et al. 2012) and enhancing the resolution of the historical, monitored, record. Mass balance estimates generated from downscaled regional climate models can also be used to bridge gaps in the data (Noël et al. 2018). However, in both of these cases, their spatial and temporal resolution often remain too low to reliably identify decadal and centennial GIC change. It is only through high-resolution analysis of Holocene glacier records that sub-millennial glacier variability can be robustly resolved.

The majority of Holocene GIC records are derived from West, South and southeast Greenland (Table 1), and show asynchronous and asymmetrical glacier dynamics over the last few millennia in response to climatic and aclimatic forcing (Balascio et al. 2015; Böning et al. 2016; Abermann et al. 2017; Vieli et al. 2017). Reconstructions of Late Holocene ice cap and mountain glacier behaviour in Greenland are frequently based on terrestrial cosmogenic nuclide dating of moraines (Young et al. 2015; Jomelli et al. 2016). However, sub-millennial glacier advanceretreat patterns are rarely well preserved in the moraine record, making it difficult to reliably identify the drivers of glacier behaviour (Balascio et al. 2015).

Unlike the geomorphological record, proglacial lakes can record continuous, high-frequency, sub-millennial, changes in glacier behaviour that can be radiocarbon 
Table 1. Records of Late Holocene (5 ka to present) glacier activity in Greenland, including proglacial lake and moraine sediment archives.

\begin{tabular}{|c|c|c|c|c|c|}
\hline Ice mass & Sedimentary record & Dating method & Age & Advance/Max/Retreat & Reference \\
\hline \multicolumn{6}{|l|}{ West Greenland } \\
\hline Uigordleq lake valley & Moraine & ${ }^{10} \mathrm{Be}$ & $820 \mathrm{a}$ & Maximum & Young et al. (2015) \\
\hline \multirow{2}{*}{ Jakobshavn Isbræ } & \multirow{2}{*}{ Marine core } & \multirow[t]{2}{*}{${ }^{14} \mathrm{C}$} & $310-450$ cal. a BP & Advance & Briner et al. $(2010,2011)$ \\
\hline & & & 100 cal. a BP & Maximum & Young et al. (2011) \\
\hline \multirow[t]{2}{*}{ Qamanaarssup Sermia } & \multirow[t]{2}{*}{ Moraine } & \multirow[t]{2}{*}{ Historical } & $250-350 \mathrm{a}$ & Advance & \multirow[t]{2}{*}{ Weidick et al. (2012) } \\
\hline & & & $150 \mathrm{a}$ & Maximum & \\
\hline Kangiata Nunaata Sermia & Lake sediment & ${ }^{14} \mathrm{C}$ & 1650 cal. a BP & Advance & Weidick et al. (2012) \\
\hline Kiagtut Sermia & Moraine & ${ }^{10} \mathrm{Be}$ & $1460 \pm 110 \mathrm{a}$ & Maximum & Winsor et al. (2014) \\
\hline \multicolumn{6}{|l|}{ North Greenland } \\
\hline Humboldt Glacier & Moraine & ${ }^{14} \mathrm{C}$ & 650 cal. a BP & Advance & Bennike (2002) \\
\hline \multicolumn{6}{|l|}{ East Greenland } \\
\hline Gurrenholm Dal glacier & Moraine & ${ }^{10} \mathrm{Be}$ & $249-749$ a & Maximum & Kelly et al. (2008) \\
\hline Bregne ice cap & Moraine & ${ }^{10} \mathrm{Be}$ & $740-9600 \mathrm{a}$ & Maximum & Levy et al. (2014) \\
\hline \multirow{2}{*}{ Istorvet ice cap } & Moraine and & ${ }^{14} \mathrm{C}$ & 800 cal. a BP & Advance & \multirow[t]{2}{*}{ Lowell et al. (2013) } \\
\hline & lake sediment & & 290 cal. a BP & Retreat & \\
\hline \multicolumn{6}{|l|}{ South Greenland } \\
\hline Kulusuk lake & Lake sediment & ${ }^{14} \mathrm{C}$ and ${ }^{210} \mathrm{~Pb}$ & From 4100 cal. a BP & Fluctuations & Balascio et al. (2015) \\
\hline
\end{tabular}

dated, providing important context for present day and future glacier retreat. Glacier-fed lake basins record variations in fine-grained (silt and clay) minerogenic sediment production resulting from glacier response to climate changes (Karlén 1981; Carrivick \& Tweed 2013). Increased glacier activity (sustained advance or retreat) leads to enhanced subglacial bedrock erosion, and a subsequent increase in sediment delivery to lake basins downstream (Leeman \& Niessen 1994; Palmer et al. 2010; MacGregor et al. 2011; Striberger et al. 2011). Depending on the bedrock mineralogical composition, increases or decreases in specific minerals in the lake record can therefore be used as a proxy for glacier activity.

High-resolution mineral analysis of proglacial lake sediments has been used to reconstruct sub-millennial Holocene glacier advance-retreat patterns and catchment change in Norway (Bakke et al. 2013), Svalbard (Gjerde et al. 2017; de Wet et al. 2018) and southeast Greenland (Balascio et al. 2015), but highly resolved proglacial lake records are scarce in High Arctic Greenland. Instead, existing studies in this region focus on palaeoecological analysis of full Holocene sequences to reconstruct local and regional climate change (Wagner et al. 2000; Klug et al. 2009a, b; Schmidt et al. 2011; Bennike \& Wagner 2012; Axford et al. 2017; Lasher et al. 2017), and glacier and ice-sheet fluctuations are not directly examined. Using detailed geochemical analysis of proglacial lake sediments, we present the first highresolution record of Late Holocene glacier behaviour in this part of High Arctic Greenland (latitude $74^{\circ} \mathrm{N}$ ).

\section{Study setting}

\section{Geological setting}

Zackenberg lies on Wollaston Foreland in High Arctic northeast Greenland $\left(74-75^{\circ} \mathrm{N}\right), \sim 50 \mathrm{~km}$ east of the GrIS
(Fig. 1A). The region is characterized by wide valleys and steep-sided plateaux and is bound by Lindeman Fjord and Tyrolerfjord to the north and south, respectively. A geological flexure and thrust zone in Zackenbergdalen $\left(74.47^{\circ} \mathrm{N}, 20.57^{\circ} \mathrm{W}\right)$ separates Cretaceous sandstones and Tertiary basalts to the east, and Caledonian gneiss to the west. The bedrock adjacent to, and probably underlying the study ice cap, Slettebreen (Fig. 1), is dominantly Proterozoic orthogneiss, with some Proterozoic or Ordovician pelitic, semi-pelitic, and psammitic metasediments (Pedersen et al. 2013). It is not currently possible to further resolve the spatial distribution of the catchment geology, due to present-day ice coverage, but our analysis shows that local lithologies are rich in silica $(\mathrm{Si})$, iron $(\mathrm{Fe})$, potassium (K), calcium (Ca) and aluminium (Al) (see Results).

\section{Climatic setting}

The regional climate is conditioned by the cold East Greenland current. This part of Greenland has a typical High Arctic climate, with mean annual air temperature of $-9{ }^{\circ} \mathrm{C}$ (annual range: $\sim-24.5^{\circ} \mathrm{C}$ to $6.6{ }^{\circ} \mathrm{C}$ ), based on 1996-2015 values measured at Zackenberg Research Base, $19 \mathrm{~km}$ from the study site (Hobbie et al. 2017). Summer (JJA) air temperatures average $4.5{ }^{\circ} \mathrm{C}$ (Hobbie et al. 2017), and precipitation $\left(\sim 200 \mathrm{~mm} \mathrm{a}^{-1}\right)$ falls predominately as snow from September to May, and rain and/or snow from June to August (Hansen et al. 2008). Rivers close to Zackenberg typically flow from June to September, and sea ice persists from October to May. The region is underlain by continuous permafrost with a $20-100 \mathrm{~cm}$ thick active layer (Christiansen et al. 2008; Christoffersen et al. 2008; Hansen et al. 2015).

\section{Glacial history and geomorphology}

High elevation erratics, trimlines and moraines have been reported up to 500 mabove sea level(a.s.1.) in the Store Sødal 

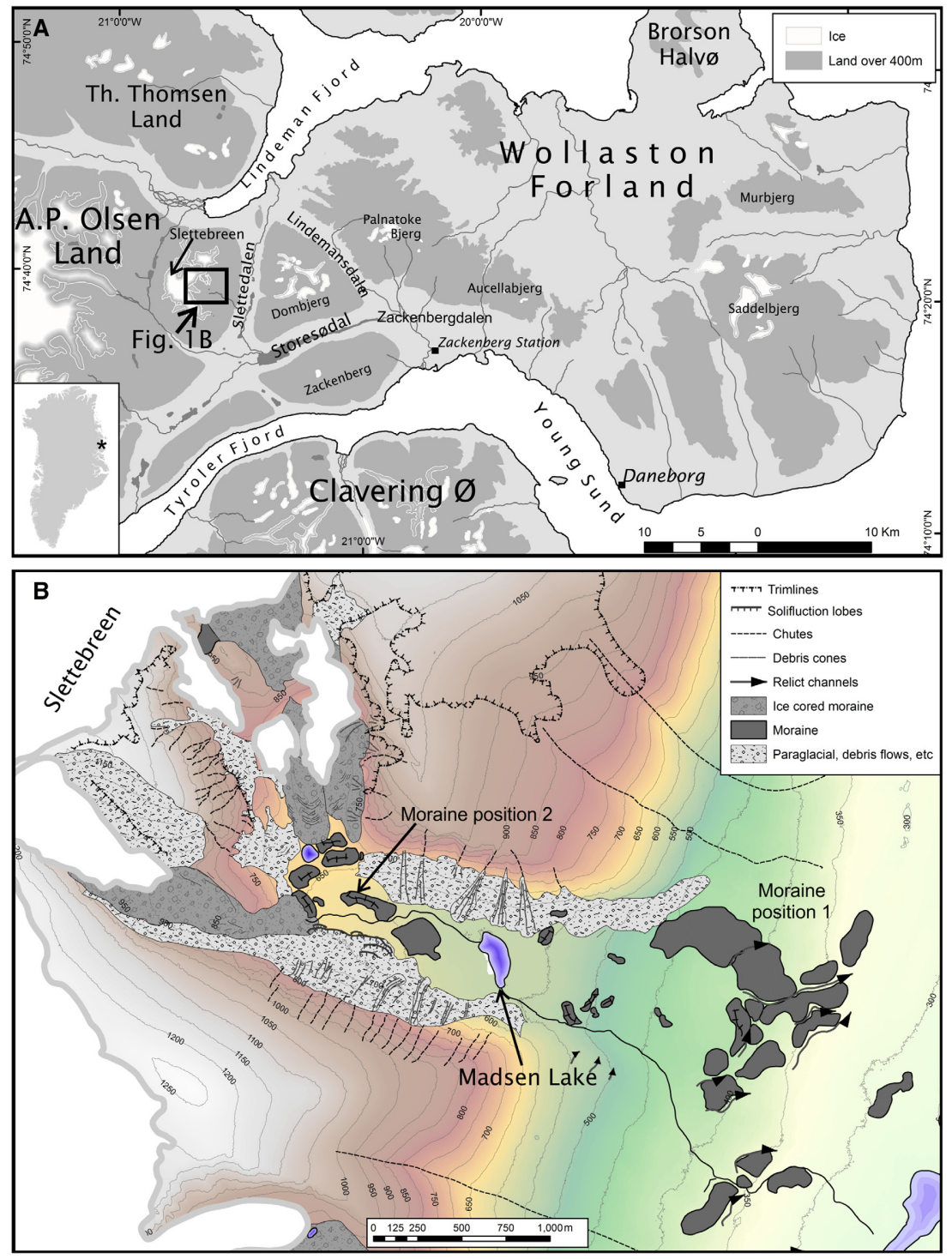

Fig. 1. A. Map of A.P. Olsen Land and Wollaston Foreland areas, showing position of Slettebreen ice cap. B. Map of the Madsen Lake catchment, showing position of outlet glaciers from Slettebreen ice cap, moraines, and periglacial slope deposits. Moraine positions M1 and M2 are indicatedsee text for discussion.

and Zackenberg valleys (Bretz 1935; Christiansen \& Humlum 1993), suggesting that outlet glaciers from the GrIS and local ice cap(s) previously extended into major valleys and fjords, and reached the shelf edge (Bennike \& Weidick 2001; Ó Cofaigh et al. 2004; Evans et al. 2009). Regional deglaciation began after the Last Glacial Maximum (LGM) and continued through the Holocene. Zackenberg valley became ice-free between 13000 and 11000 years ago (Gilbert et al. 2017), but the time by which glaciers reached their present position is currently unknown.

\section{Slettebreen ice cap and study catchment}

Slettebreen $\left(\sim 17 \mathrm{~km}^{2}\right)$ is largely confined to an upland plateau (1200 m a.s.1.) and is drained by six outlet glaciers to the south and east, and one to the north that extends to $450 \mathrm{~m}$ a.s.l. and displays evidence of surge activity (periodic increases in flow speeds unrelated to external triggers; Meier \& Post 1969; Sharp et al. 1988). Large, undated, moraines beyond the present-day ice margins indicate that Slettebreen's outlet glaciers previously extended radially, towards Slettedalen, Storesødal, and Lindeman Fjord. Based on the established area-altitude balance ratio (AABR) method (Rea 2009) Slettedalen's current equilibrium line altitude (ELA) is estimated at 1071-1081 m a.s.1. (AABRs of 1.67-2.0).

The study lake $\left(74.58^{\circ} \mathrm{N}, 21.07^{\circ} \mathrm{W}, 504 \mathrm{~m}\right.$ a.s.1.), previously unnamed and hereafter referred to as Madsen Lake (area $=0.04 \mathrm{~km}^{2}$, depth $\left.=2 \mathrm{~m}\right)$, occupies a steepsided over-deepened basin $\sim 1.6 \mathrm{~km}$ from the eastern 
margins of Slettebreen, and is fed by three small outlet glaciers (Figs 1A, B, 2) that currently terminate on the flanks of the plateau, $\sim 0.8-1.5 \mathrm{~km}$ from the plateau edge. The lake catchment contains ice-moulded bedrock, unconsolidated glacial, glacifluvial and colluvial sediment, and sparse tundra vegetation. The small catchment area and proximity to the margins of Slettebreen mean that sediment storage between the glacier and lake is limited, non-glacial sediment input is minimized, and the basin provides a reliable record of glacier behaviour.

Based on morphostratigraphical similarities with other Greenlandic basins (Weidick 1968; Kelly \& Lowell 2009), and the freshness of landforms, two moraine positions are identified in the Madsen Lake basin. Position 1 is a large, undated, moraine complex downstream of the lake, thought to correspond to a period of stillstand during retreat from the LGM position (Fig. 1B). Position 2, upstream of the lake, is a complex of moraine ridges thought to correspond to the most recent phase of glacier advance during the Late Holocene, possibly associated with the Little Ice Age (LIA), and suggests that the Madsen Lake basin was not overridden by ice at that time. Given the knowledge of Greenlandic glacier behaviour during this period (Kelly \& Lowell 2009), it is likely that Position 2 moraines formed during a regrowth of ice, following the Holocene Thermal Maximum. The reconstructed palaeo-ELAs (AABRs 1.67-2.0) at Moraine Positions 1 and 2 are 761-784 m a.s.l. and 959-975 m a.s.1., respectively.

\section{Material and methods}

\section{Lake sediment coring}

Lake cores were taken in spring (May), when the surface of Madsen Lake was frozen. Suitable coring locations were established using aerial photographs, satellite imagery and ArcticDEM data, which identified a deep central lake basin and shallower rim. Samples were taken from the deepest part of the central basin, to avoid reworked sediment or sediment gravity flows. Cores were obtained using a Russian-type corer, capturing the water-sediment interface and extending to a maximum sediment depth of $80 \mathrm{~cm}$, before striking bedrock or boulders. The core was subsampled with a scalpel in the field at $1.0-$ and $0.5-\mathrm{cm}$ resolution, depending on water content.

\section{Laboratory analysis}

Sediment grain size was measured using a Malvern Mastersizer 2000 and Hydro 2000G liquid handling unit, with triplicate measurements and bracketing cleaning cycles. Prior to analysis, organic matter was removed using $40 \%$ hydrogen peroxide, and samples were dispersed in sodium hexametaphosphate solution. Particle size distribution was modelled using a Mie Theory estimation model configured for silica sand, which is particularly effective for grains $<10 \mu \mathrm{m}$, such as the fine-grained Madsen Lake sediments. Particle size analysis (PSA) was used to calculate GSD90, the 90th percentile of grain-size distribution.

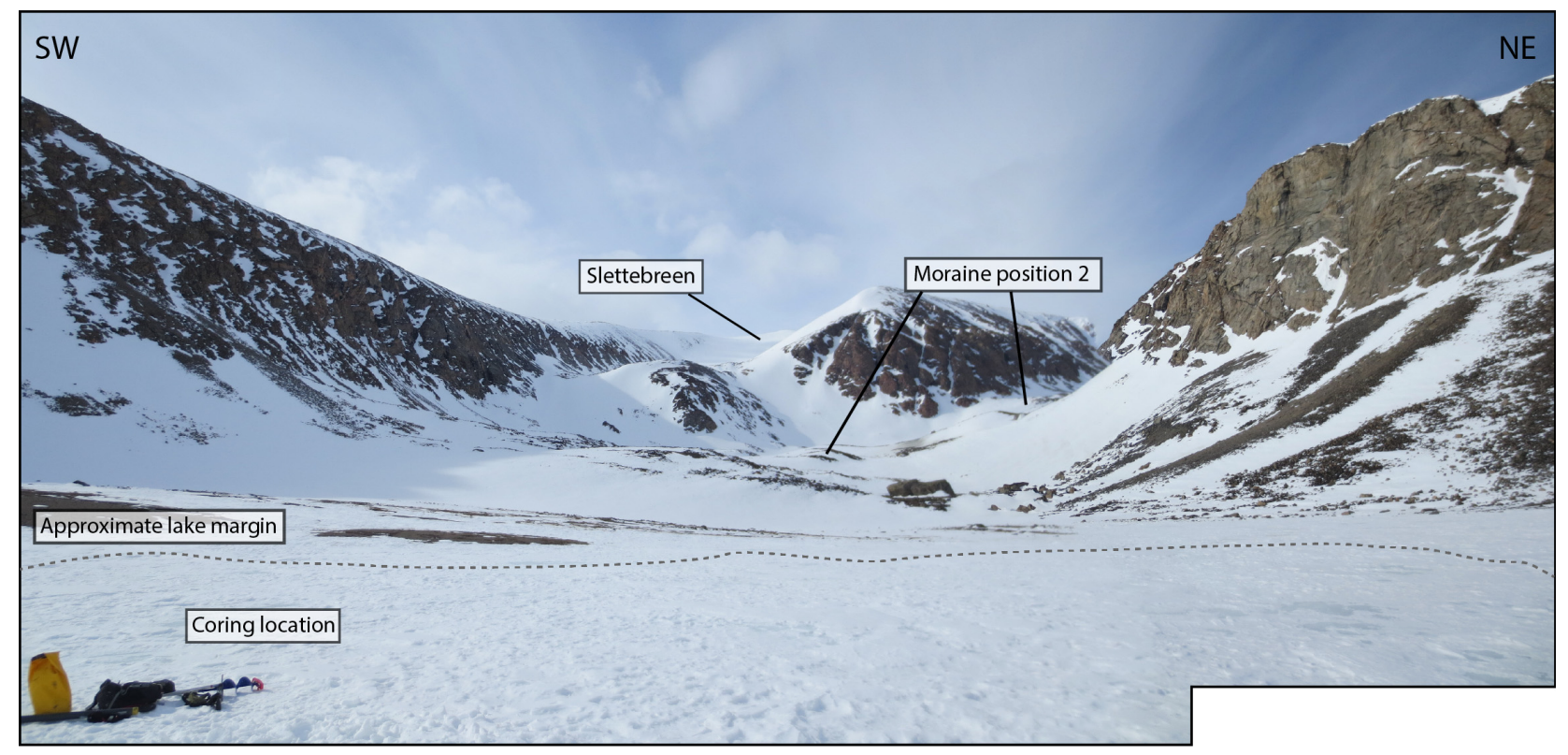

Fig. 2. The Madsen Lake catchment. The margins of Slettebreen are out of view in the centre of the image. The steep valley sides and debris-covered slopes are visible beneath the snow cover. Note the ice drill and bag for scale. 
Samples were freeze-dried prior to elemental, mineralogical, magnetic and carbon analysis and pressed (at $3.5 \mathrm{n} \mathrm{kg}^{-1}$ ) into Chemplex 1330 sample holders with a $4 \mu \mathrm{m}$ Mylar film window. Sediment elemental composition (X-ray fluorescence, XRF) was analysed using a Rigaku NEX-CG with an RPF-SQX scattered ray FP method (Helium-purged). This system uses a 'Rigaku Profiling Fitting-Spectra Quant X' algorithm to provide elemental mass estimates. Sample mineralogy (X-ray powder diffraction data, XRD) was collected using a PANalytical X'Pert diffractometer fitted with a PixCEL 1$\mathrm{D}$ detector using a $\mathrm{Cu}$ anode $\left(\mathrm{k} \alpha_{1} \lambda=0.5406 \AA\right)$ with the generator set at $40 \mathrm{~mA}, 40 \mathrm{kV}$. Samples were prepared as flat powder and collected in transmission geometry in the range $5-120^{\circ} 2 \theta$ with a step size of $0.013^{\circ} 2 \theta$ and a collection time of $118 \mathrm{~s} \mathrm{step}^{-1}$ using automatic divergence and antiscatter slits with an observed length of $8.0 \mathrm{~mm}$. Data were processed using HighScore Plus version 4.0.

Eight clasts from Slettedalen were crushed and analysed for elemental (XRF) and mineralogical (XRD) composition. Pebbles were selected in the field on the basis that they are representative of local bedrock lithologies, delivered from meltwater streams draining Slettebreen, and can be used to compare to lake sediment geochemical signatures.

A Bartington MS2B sensor and MS3 interface were used to measure sediment magnetic susceptibility (MS) at high frequency $\left(\chi_{\mathrm{hf}}\right)$. Corrections for sample volume follow Dearing (1999). MS is a relative measure of the magnetization of minerals, and in a sedimentary sequence can be influenced by factors including changes in clastic sediment content, erosion of different source rocks, and time-dependent weathering.

Total organic carbon (TOC) was measured using a Shimadzu TOC-VSSI analyser, with $\sim 40 \mathrm{mg}$ of freezedried sediment in crucibles capped with inert glass wool. Samples were analysed according to machine standard protocols for sediment samples, and $10 \mathrm{mg}$ glucose standard. 20 random samples from the core succession were tested for inorganic carbon, and all yielded results below detection limits.

\section{Statistical analysis}

Principal components analysis (PCA), which establishes the leading mode of data variability (expressed as the first component), was performed using 10 elements from the XRF data selected on the basis of abundance in the lake sediments and bedrock clast samples (Al, K, Ca, Rb, Ti, Fe, $\mathrm{Si}, \mathrm{Mg}, \mathrm{Mn}$ and $\mathrm{Sr}$ ). Data were centre-log-ratio transformed, and two outlier samples (at 42.0-43.0 and 60.5$61.0 \mathrm{~cm}$ ) were removed. Analysis was performed in R v. 3.4.2 (R Core Team 2017) and transformed using the chemometrics v. 0.1 package (Filzmoser \& Varmuza 2017).

Cluster analysis of the XRD data was used to examine the mineralogical signatures of the sedimentary units, to provide additional detail about the geochemical compo- sition (XRF), and thus test for fundamental differences between depositional phases. HighScore Plus (v. 4.0) used diffraction peak position and profile as the data source, and position and intensity (as a measure of crystalline concentrations) as the comparison criteria. Cluster assignments were validated by fuzzy clustering, which assigns each data set to a parent cluster based on a figure of merit, which is indicative of the strength and reliability of cluster assignments. This method is especially beneficial as it enables data sets to be evaluated within multiple clusters to yield the most appropriate cluster assignments. Relative intensity of the diffraction peaks was used to calculate the relative abundance of dominant minerals within each cluster.

\section{Core chronology}

The lake core chronology is based on four radiocarbon $\left({ }^{14} \mathrm{C}\right)$ ages of in situ organic macrofossils (undifferentiated bryophytes) taken from individual laminae, avoiding sampling across multiple laminations; samples were analysed at Beta Analytic (Table 2). Calibration and agedepth modelling were performed in Bacon v. 2.3.3 (Blaauw \& Christen 2011) using the IntCal13 (Reimer et al. 2013) radiocarbon calibration curve. The Bacon algorithm is a Bayesian approach to accumulation rate modelling and the default parameters were used throughout.

\section{Results}

\section{Catchment lithology and geochemistry}

Eight clast samples represent five lithological categories: quartz, gneiss, granite, unakite and sandstone. XRF data show that all clasts are rich in $\mathrm{Si}$ (typically 22.4-32.0 mass $\%$ ) as well as $\mathrm{Al}, \mathrm{Ca}, \mathrm{Fe}, \mathrm{Na}$, Ti and $\mathrm{Mg}$ (Table 4). The high concentrations of these minerals make them suitable for tracking glacial erosion, and they were therefore selected for use in this study. Other elements such as Rh, P, Zr, Mn, $\mathrm{Sr}, \mathrm{Rb}$ and $\mathrm{Ba}$ are present in lower abundance (typically 0.5-0.02 mass \%). XRD analysis indicates that the dominant mineral constituents include quartz, biotite, orthoclase and epidote. The clast elemental composition and mineral signatures are reflected in the lake sedimentary succession, described below.

\section{Lake stratigraphy and sediment characteristics}

Five stratigraphical units have been identified based on sedimentology, physical characteristics (particle size, dry bulk density (DBD), TOC (indicator of organic matter) and MS (a relative indicator of clastic sediment composition), Table 3), and geochemistry (XRF and XRD). Figure 3 focuses on selected elements present in the lake sediments and local bedrock (Table 4), and their ratios, which fluctuate according to the sequence stratigraphy. 
Table 2. Radiocarbon ages of plant macrofossil samples (ZAC-1 to ZAC-4), calibrated using the Intcall3 curve. Calendar ages are displayed for comparison with climate records. All samples were prepared and analysed at Beta Analytic.

\begin{tabular}{|c|c|c|c|c|c|c|c|c|c|}
\hline Sample number & Beta code & $\begin{array}{l}\text { Core } \\
\text { depth }(\mathrm{cm})\end{array}$ & $\begin{array}{l}\text { Sample } \\
\text { material }\end{array}$ & $\begin{array}{l}\text { Sample } \\
\text { mass (mg) }\end{array}$ & ${ }^{14} \mathrm{C}$ age (a BP) & Error $( \pm 1 \sigma)$ & Age (cal. a BP, $2 \sigma$ ) & $\begin{array}{l}\text { Calendar } \\
\text { age (CE) }\end{array}$ & $\Delta{ }^{13} \mathrm{C}$ \\
\hline ZAC-1 & 466979 & $6.0-7.0$ & Plant & 2.60 & 620 & 30 & $658-550$ & $1292-1400$ & -26.3 \\
\hline ZAC-2 & 469962 & $11.0-12.0$ & Plant & 0.93 & 660 & 30 & $\begin{array}{l}603-557 \\
674-628\end{array}$ & $\begin{array}{l}1347-1393 \\
1276-1322\end{array}$ & -29.5 \\
\hline ZAC-3 & 469963 & $59.0-60.0$ & Plant & 1.00 & 1390 & 30 & $1348-1276$ & $602-674$ & -25.1 \\
\hline ZAC-4 & 480589 & $76.0-76.5$ & Plant & 0.52 & 1730 & 50 & $1740-1535$ & $210-415$ & -23.8 \\
\hline
\end{tabular}

On this basis, elemental signatures are used as proxies for glacier behaviour and lake basin conditions. Ti and Ti/Al ratios are indicators of detrital clastic sediment input and associated glacier activity, consistent with local lithologies and ratios, and used elsewhere (Bakke et al. 2009, 2013). $\mathrm{Rb} / \mathrm{Sr}$ ratios are used as an indicator of chemical weathering within the lake catchment (Vasskog et al. 2011), as Sr, which has an affinity with $\mathrm{Ca}$, is easily released during chemical weathering. $\mathrm{Si} / \mathrm{Ti}$ ratios are commonly used as an indirect proxy of lake productivity, reflecting changes in biogenic silica input (Melles et al. 2012; Gjerde et al. 2017). The $\mathrm{Mn} / \mathrm{Fe}$ ratio indicate levels of anoxia, as Mn oxidizes more rapidly than Fe leading to higher ratios under oxidizing conditions (Naeher et al. 2013; Gjerde et al. 2017).

The first and second components of the PCA account for approximately 66 and $13 \%$ of the sample variance, respectively (Fig. 4). Component 1 scores accurately reproduce the stratigraphical units (Fig. 3).

Unit A (80-60 cm depth) - siltyclay gyttja. - At the base of the core, bedrock or boulders are overlain by firm, grey clay $(\sim 80-76 \mathrm{~cm})$, which grades upwards to more organic, crudely stratified brown silty clay gyttja (Fig. 3). The upper part of the unit is abundant in bryophytes. This unit has low DBD $\left(0.78-1.36\right.$, mean $\left.1.02 \mathrm{~g} \mathrm{~cm}^{-3}\right)$ and MS $\left(8.30-47.10 \times 10^{-5} \chi_{\mathrm{hf}}\right.$, mean $\left.17.86 \times 10^{-5} \chi_{\mathrm{hf}}\right)$, and high TOC (1.49-6.05, mean $2.69 \%$ ). Mean grain sizes range from 17.42 to $32.41 \mu \mathrm{m}$ (fine silt and clay). Fluctuations in elemental composition (e.g. Ca, Ti) probably reflect variations in minerogenic sediment content. $\mathrm{Si} / \mathrm{Ti}$ and $\mathrm{Rb} / \mathrm{Sr}$ ratios remain high throughout this unit, while $\mathrm{Ti} / \mathrm{Al}$ and $\mathrm{Mn} / \mathrm{Fe}$ are low.
Unit B (60-51 cm depth) - laminated silt and clay. - Unit $B$ has a sharp contact with unit $A$ and contains laminated grey clays and silts, with negligible organic matter (Fig. 3). Laminations are $<1-3 \mathrm{~mm}$ thick, with mean grain sizes of 11.53-30.57 $\mu \mathrm{m}$. DBD (1.07-1.52, mean $\left.1.31 \mathrm{~g} \mathrm{~cm}^{-3}\right)$ and MS $\left(16.67-126.54 \times 10^{-5} \chi_{\mathrm{hf}}\right.$, mean $\left.47.70 \times 10^{-5} \chi_{\mathrm{hf}}\right)$ values increase sharply at the lower boundary, with the shift to minerogenic sediment. Ca and Ti concentrations are high compared to the underlying more organic unit and decrease markedly at the upper boundary. Low $\mathrm{Si} / \mathrm{Ti}$ and $\mathrm{Rb} / \mathrm{Sr}$ ratios and high Ti/Al and $\mathrm{Mn} / \mathrm{Fe}$ ratios are consistent with low TOC values $(0.43-$ 0.67 , mean $0.54 \%$ ) and are indicative of high minerogenic sediment input and greatly reduced biological activity.

Unit C (51-32 cm depth) - gyttja, silt, and clay. - This unit has a gradational lower contact, and grades upwards to faintly laminated brown gyttja, silt, and clay, with fluctuating organic and minerogenic components (mean grain sizes 17.87-42.60 $\mu \mathrm{m})$. DBD $(0.80-1.26$, mean 0.96 $\left.\mathrm{g} \mathrm{cm}^{-3}\right)$, MS $\left(6.15-30.66 \times 10^{-5} \chi_{\mathrm{hf}}\right.$, mean $19.38 \times 10^{-5}$ $\chi_{\mathrm{hf}}$ ) and elemental values (notably $\mathrm{Ca}, \mathrm{Al}, \mathrm{Ti}$ and $\mathrm{Si}$ ) are similar to Unit A (Fig. 3). High Si/Ti ratios and TOC (0.77-5.18, mean 3.66\%), as well as high Rb/Sr and low Ti/ $\mathrm{Al}$ and $\mathrm{Mn} / \mathrm{Fe}$ ratios, suggest limited detrital sediment input and reduced bedrock weathering and erosion (Table 3).

Unit D (32-23 cm depth) - laminated silt and clay. - The laminated grey silts and clays in Unit D record an abrupt shift in physical properties and elemental composition, despite the gradational sedimentological contacts (Fig. 3). The unit has high DBD (1.12-1.73, mean $\left.1.33 \mathrm{~g} \mathrm{~cm}^{-3}\right)$

Table 3. Sediment characteristics of the Madsen Lake sequence with minimum, maximum, mean and standard deviation values. Horizons B, D and E2, associated with enhanced glacier activity, are indicated in italics.

\begin{tabular}{|c|c|c|c|c|c|c|c|c|c|c|c|c|c|c|c|c|c|}
\hline \multirow[t]{2}{*}{ Unit } & \multirow[t]{2}{*}{$\begin{array}{l}\text { Acc. rate } \\
\left(\mathrm{mm} \mathrm{a}^{-1}\right)\end{array}$} & \multicolumn{4}{|c|}{$\begin{array}{l}\text { Mean grain size } \\
(\mu \mathrm{m})\end{array}$} & \multicolumn{4}{|c|}{$\begin{array}{l}\text { Total organic carbon } \\
(\%)\end{array}$} & \multicolumn{4}{|c|}{$\begin{array}{l}\text { Dry bulk density } \\
\left(\mathrm{g} \mathrm{cm}^{-3}\right)\end{array}$} & \multicolumn{4}{|c|}{$\begin{array}{l}\text { Magnetic susceptibility } \\
\mathrm{t}\left(\times 10^{-5} \chi_{\mathrm{hf}}\right)\end{array}$} \\
\hline & & Min & Max & Mean & Std. & Min & Max & Mean & Std. & Min & Max & Mean & Std. & Min & Max & Mean & Std. \\
\hline E3 & & 25.97 & 33.72 & 30.23 & 2.19 & 0.81 & 1.75 & 1.24 & 0.28 & 1.04 & 1.32 & 1.22 & 0.07 & 52.23 & 141.73 & 86.60 & 30.54 \\
\hline E2 & 0.28 & 26.32 & 41.97 & 26.32 & 5.75 & 0.78 & 1.22 & 0.92 & 0.19 & 1.21 & 1.39 & 1.32 & 0.06 & 82.08 & 229.33 & 171.94 & 63.31 \\
\hline E1 & & 8.46 & 26.45 & 21.54 & 6.33 & 0.94 & 1.77 & 1.39 & 0.30 & 1.10 & 1.23 & 1.16 & 0.04 & 51.89 & 136.28 & 97.34 & 24.85 \\
\hline$D$ & 0.72 & 9.61 & 38.17 & 25.11 & 8.97 & 0.82 & 3.57 & 1.47 & 0.81 & 1.12 & 1.73 & 1.33 & 0.16 & 27.19 & 127.12 & 86.17 & 28.78 \\
\hline C & 0.64 & 17.87 & 42.60 & 23.59 & 6.15 & 0.77 & 5.18 & 3.66 & 1.24 & 0.80 & 1.26 & 0.96 & 0.12 & 6.15 & 30.66 & 19.38 & 6.01 \\
\hline B & 0.37 & 11.53 & 30.57 & 21.74 & 5.67 & 0.43 & 0.67 & 0.54 & 0.08 & 1.07 & 1.52 & 1.31 & 0.13 & 16.67 & 126.54 & 47.70 & 24.16 \\
\hline A & 0.29 & 17.42 & 32.41 & 23.21 & 2.98 & 1.49 & 6.05 & 2.69 & 1.10 & 0.78 & 1.36 & 1.02 & 0.13 & 8.30 & 47.10 & 17.86 & 8.16 \\
\hline
\end{tabular}




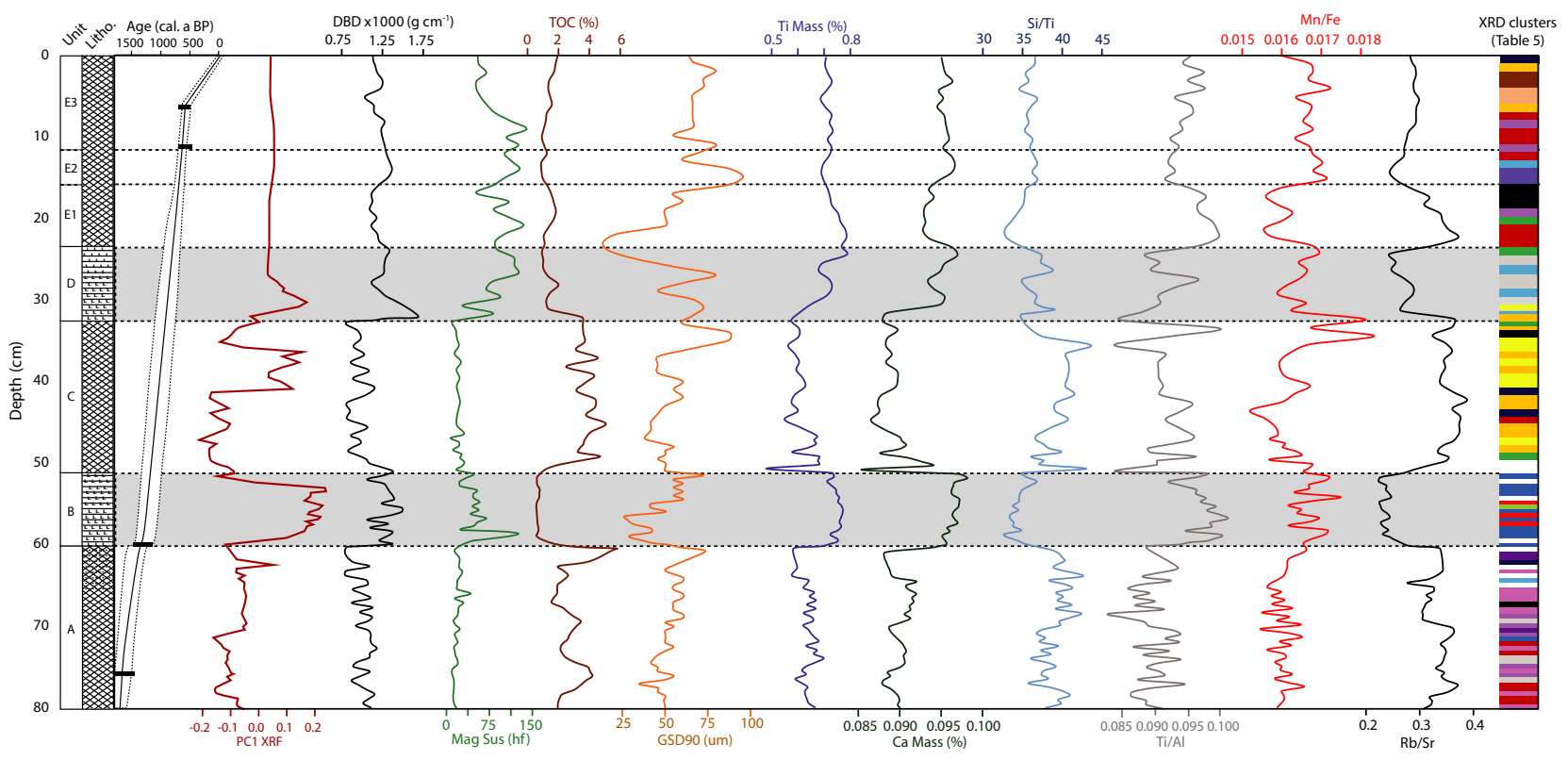

Fig. 3. Physical and geochemical plot of the Madsen Lake sediment succession, including unit lithology following Troels-Smith (1955). Physical characteristics: dry bulk density (DBD), magnetic susceptibility (Mag Sus), total organic carbon (\%), GSD90 and selected elemental compositions: $\mathrm{Ti}, \mathrm{Ca}$ and ratios $\mathrm{Si} / \mathrm{Ti}$ (an indirect indicator of lake productivity), $\mathrm{Ti} / \mathrm{Al}$ (detrital sediment inputs), $\mathrm{Mn} / \mathrm{Fe}$ (oxic vs. anoxic conditions) and $\mathrm{Rb} / \mathrm{Sr}$ (weathering). XRF PC1 scores are shown. XRD cluster assignments are indicated at the right of the geochemistry plot - see Table 5 for cluster composition data. (For interpretation of the references to colour in this figure, the reader is referred to the web version of this article).

and low TOC (0.82-3.57, mean $1.47 \%)$. Ca, Ti and MS $\left(27.19-127.12 \times 10^{-5} \chi_{\mathrm{hf}}\right.$, mean $\left.86.17 \times 10^{-5} \chi_{\mathrm{hf}}\right)$ increase markedly at the lower contact, and a decrease in $\mathrm{Rb} / \mathrm{Sr}$ ratios, compared to Unit $\mathrm{C}$, suggests enhanced input of weathered, minerogenic sediment.

Unit E (23-0 cm depth) - faintly laminated gyttja, silt, and clay. - Unit E contains faintly laminated brown gyttja, silt, and clay $(8.46-41.97 \mu \mathrm{m})$. Despite uniform sedimentology, geochemical measurements and ordination results (Fig. 3) identify three depositional phases, divided into subunits E1, E2 and E3.

Subunit E1 $(23-16 \mathrm{~cm})$ coarsens upwards, and has relatively high DBD $\left(1.10-1.23\right.$, mean $\left.1.16 \mathrm{~g} \mathrm{~cm}^{-3}\right)$ and MS (51.89-136.28 × $10^{-5} \chi_{\mathrm{hf}}$, mean $\left.97.34 \times 10^{-5} \chi_{\mathrm{hf}}\right)$

Table 4. Lithology and elemental composition (XRF, eight most abundant elements, mass \%) of clast samples from the study region around Madsen Lake and Slettedalen. See text for further details of less abundant elements.

\begin{tabular}{lllllllll}
\hline Lithology & \multicolumn{1}{l}{ Elemental composition (mass \%) } \\
\cline { 2 - 9 } & $\mathrm{Si}$ & $\mathrm{Al}$ & $\mathrm{Ca}$ & $\mathrm{K}$ & $\mathrm{Fe}$ & $\mathrm{Na}$ & $\mathrm{Mg}$ & $\mathrm{Ti}$ \\
\hline Sandstone & 22.40 & 7.22 & 7.35 & 0.21 & 9.74 & 2.60 & 1.72 & 1.28 \\
Gneiss & 27.30 & 5.99 & 1.46 & 3.24 & 2.65 & 2.89 & 0.73 & 0.32 \\
Gneiss & 26.80 & 6.70 & 2.82 & 3.20 & 3.12 & 2.43 & 0.89 & 0.49 \\
Unakite & 32.00 & 6.33 & 4.35 & 2.30 & 2.21 & 2.15 & 0.39 & 0.21 \\
Granite & 23.40 & 6.88 & 5.13 & 3.93 & 6.69 & 1.76 & 2.25 & 0.52 \\
Granite & 27.90 & 6.37 & 0.57 & 3.96 & 2.27 & 2.86 & 0.55 & 0.29 \\
Granite & 26.00 & 6.48 & 5.28 & 0.82 & 4.18 & 2.90 & 2.64 & 0.20 \\
Quartz & 27.30 & 7.77 & 0.13 & 8.83 & 0.03 & 1.61 & 0.05 & 0.01 \\
\hline
\end{tabular}

and low TOC (0.94-1.77, mean $1.39 \%)$. Ca and $\mathrm{Mn} / \mathrm{Fe}$ values decrease sharply at the lower boundary and remain low throughout. Ti/Al and $\mathrm{Rb} / \mathrm{Sr}$ ratios, as well as PCA component 1 scores (PC1), increase rapidly at the lower contact, before gradually decreasing.

E2 $(16-12 \mathrm{~cm})$, which broadly fines upwards, has high DBD (1.21-1.39, mean $\left.1.32 \mathrm{~g} \mathrm{~cm}^{-3}\right)$ and MS (82.08$229.33 \times 10^{-5} \chi_{\mathrm{hf}}$, mean $\left.171.94 \times 10^{-5} \chi_{\mathrm{hf}}\right)$, and low TOC $(0.78-1.22$, mean $0.92 \%)$. Through this subunit, Ti values reduce, $\mathrm{Ca}$ values increase and $\mathrm{Rb} / \mathrm{Sr}$ decreases considerably before increasing towards the upper contact. These elemental profiles are reflected in an increase in PC1 scores towards the top of the subunit.

Subunit E3 $(12-0 \mathrm{~cm})$ has relatively high DBD (1.041.32 , mean $\left.1.22 \mathrm{~g} \mathrm{~cm}^{-3}\right)$ and MS (52.23-141.73 $\chi_{\mathrm{hf}}$, mean $\left.86.60 \chi_{\mathrm{hf}}\right)$. TOC $(0.81-1.75$, mean $1.24 \%)$ increases towards the top of the succession, while MS progressively decreases. Grain-size, Ti, $\mathrm{Ca}, \mathrm{Si} / \mathrm{Ti}$ and $\mathrm{Rb} / \mathrm{Sr}$ values show little variation, but $\mathrm{Ti} / \mathrm{Al}$ ratios gradually increase with height. These elemental profiles are also reflected in the stable PC1 scores.

\section{Lake sediment $X$-ray diffraction and cluster analysis}

The Madsen Lake sediments show a complex, but relatively uniform mineralogy throughout the succession, and a dominance of richterite, phlogopite, orthoclase, quartz, chamosite and albite. The samples share a common spectrum and clusters reflect variations in the relative abundance of the same suite of minerals. Cluster 


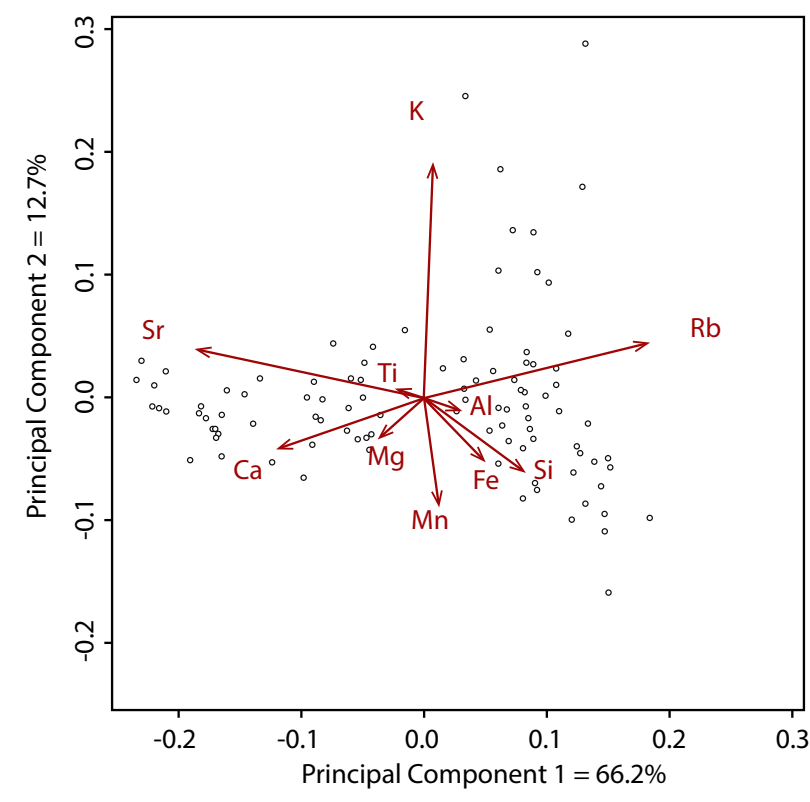

Fig. 4. PCA plot of 10 elements (XRF analysis) selected on the basis of their abundance in the bedrock and lake sediments. Axis 1 accounts for approximately $66 \%$ of the sample variance. Axis 2 represents approximately $13 \%$ of the sample variance. Open circles represent each sampled horizon.

analysis identifies 14 different mineralogical clusters (Table 5, Fig. 3). When plotted against core stratigraphy, five distinct populations are apparent, which correspond to the sedimentary units A-E and to XRF data (Fig. 3). Importantly, clusters show that the mineralogical signatures of the laminated clay units (B and D) are distinct from the less minerogenic horizons (Units A and C). Unit E2 shares similar cluster assignments to the underlying clay units (B and D).

\section{Chronology}

The Madsen Lake chronology is constrained by four ${ }^{14} \mathrm{C}$ ages from plant macrofossils. Some units have not been directly dated, due to unsuitable material for ${ }^{14} \mathrm{C}$ analysis, and their age has been estimated using the age-depth model (Fig. 3). Dates are expressed as calibrated years before $1950 \mathrm{CE}$ (Common Era; cal. a BP) unless otherwise stated. A sample from the base of Unit A (ZAC-4, 76.0-76.5 cm depth), close to the onset of lake sedimentation, is dated to $1740-1535$ cal. a BP Sample ZAC-3 from the base of Unit B (59.0-60.0 cm depth) yields an age of 1322-1276 cal. a BP, marking the onset of a laminated silt and clay depositional phase.

The presence of a sharp, potentially erosive, contact between Units A and $\mathrm{B}(60 \mathrm{~cm})$ is represented in the agedepth model as a hiatus. The inclusion of a hiatus increases the uncertainties for this section of the agedepth model, but age control provided by samples ZAC-4 and ZAC-3 means that palaeoenvironmental interpretations are unaffected. Two samples from Unit E yielded ages of 603-557 cal. a BP (sample ZAC-1, 6.0-7.0 cm depth) and 658-550 cal. a BP (sample ZAC-2, 11.0$12.0 \mathrm{~cm}$ depth). The overlapping calibrated age range of ZAC-1 and ZAC-2 is a product of the ${ }^{14} \mathrm{C}$ calibration curve plateau (Hallstatt plateau) and is not thought to reflect a true age inversion of the sample (Jacobsson et al. 2018). Above these dated horizons, the upper-most laminations remain horizontally bedded, but it cannot be ruled out that this part of the succession (i.e. 0.0 $7.0 \mathrm{~cm}$ ) has been truncated due to poor recovery at the sediment-water interface. This cannot be tested with the current chronology, but it does not affect interpretations of the central portion of the core.

Modelled sediment accumulation rates for each unit, based on the age-depth model, are $0.29 \mathrm{~mm} \mathrm{a}^{-1}$ (Unit A), $0.37 \mathrm{~mm} \mathrm{a}^{-1}$ (Unit B), $0.64 \mathrm{~mm} \mathrm{a}^{-1}$ (Unit C), $0.72 \mathrm{~mm}$ $\mathrm{a}^{-1}$ (Unit D) and $0.28 \mathrm{~mm} \mathrm{a}^{-1}$ (Unit E). However, given the variations in grain size, minerogenic content and changes in dry bulk density within the units, alongside the evidence for a possible erosive contact between Units A and $\mathrm{B}$, it is likely that the rate has varied.

\section{Discussion}

\section{Madsen Lake catchment history}

Three phases of enhanced glacier activity, indicated by increased minerogenic sediment input, are recorded in the Madsen Lake succession. Two of these are recorded by distinct intervals of laminated clay and silt (Units B and D; Fig. 3) and a corresponding shift in geochemical characteristics. We interpret these units as evidence for a phase of glacial advance and retreat (contained within Unit B) followed by a period of re-advance (Unit D). These phases are separated by a unit of lower minerogenic sediment content, representing conditions of reduced glacial activity (Unit C). A less marked reduction in minerogenic input (Unit E1), coupled with continuing low TOC levels, may be due to ice recession and/ or reduced glacial erosion and sediment excavation. A third, shorter phase of enhanced glacial activity is identified by the geochemical record of Unit E2, followed by a transition towards the top of the succession to conditions with lower glacial sediment input to the lake.

These shifts in minerogenic and geochemical characteristics are consistent with other proglacial lake sediment records in Svalbard (Gjerde et al. 2017; de Wet et al. 2018) and Greenland (Van der Bilt et al. 2018), where minerogenic horizons are characterized by reduced TOC, and an increase in DBD, MS, and elements such as Fe, Ti and $\mathrm{Ca}$. Variations in the degree of development and thickness of glacial lake sediment laminations are common and reflect changes in the depositional environment. These include sediment inputs into the basin, fluctuations in lake water depth, which in turn control distance from lake sediment inputs, the development of thermal and density stratification, 
Table 5. Relative abundance of the dominant minerals present within the 14 Lake Madsen XRD clusters (see Fig. 3 for down-core cluster assignments) based on the relative intensity of diffraction peaks, which are indicative of crystalline concentrations.

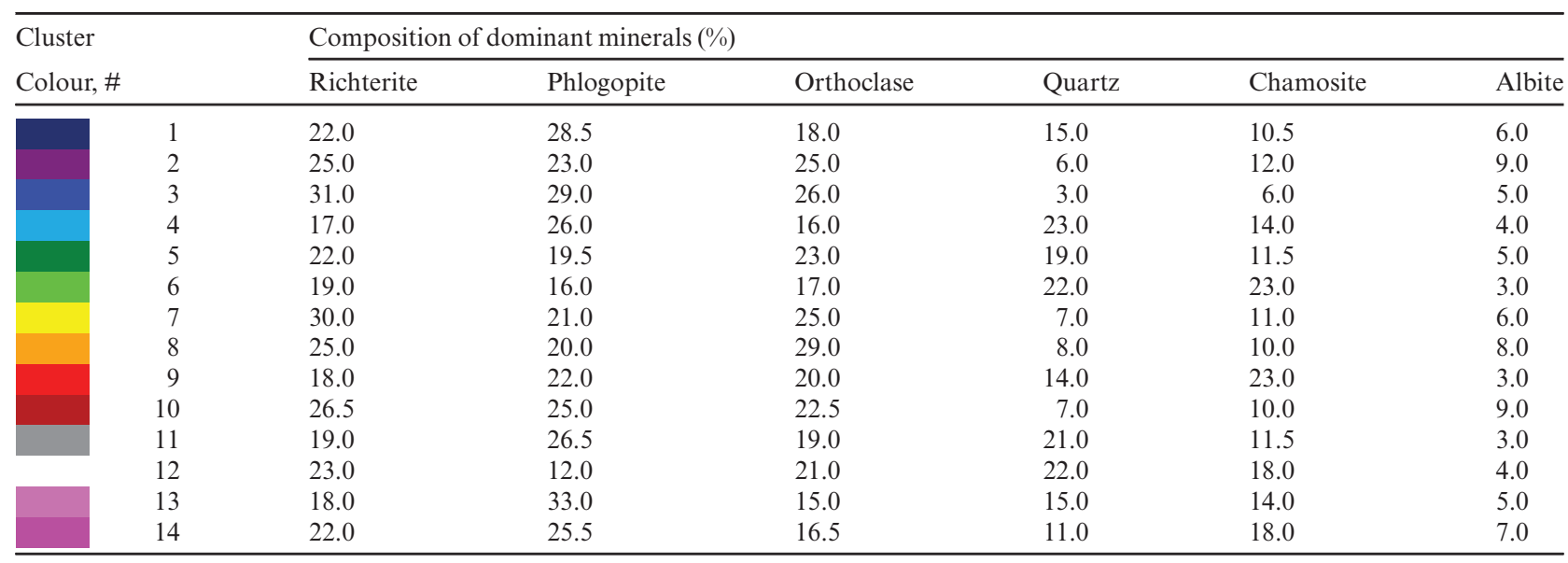

and the likelihood of reworking and homogenization of sediments by bioturbation and wave action (Zillén et al. 2003; Zolitschka et al. 2015).

The Madsen Lake depositional history is outlined below. Unit ages have been assigned as modelled ages from the age-depth model based on four ${ }^{14} \mathrm{C}$ ages (ZAC-1 to ZAC4). It is important to note that, although three phases of enhanced glacier activity are recorded between 1322 and 1276 cal. a BP (ZAC-3, 59.0-60.0 cm) and 658-550 cal. a BP (ZAC-2, 11.0-12.0 cm), only the base of Unit B has been directly dated, and modelled ages are discussed with appropriate caution.

Prior to $1740-1535$ cal. a BP, outlet glaciers from the eastern margins of Slettebreen coalesced and advanced beyond the lake basin, depositing a large suite of moraines at the margins of Slettedalen (Moraine Position 1, Fig. 1). Following ice retreat and exposure of the lake basin, sedimentation began at c. 1740-1535 cal. a BP (Unit A). Low and fluctuating minerogenic sediment inputs, low $\mathrm{DBD}$, and relatively increased TOC and $\mathrm{Si} / \mathrm{Ti}$ ratios suggest that glacigenic sediment supply was low and that the ice margin was situated upvalley, possibly close to the present-day ice margins.

A period of glacial advance into the lower catchment ( $c$. 1350-1190 cal. a BP) is recorded by a sharp contact into the laminated silts and clays of Unit B, together with an increase in DBD and a decrease in $\mathrm{TOC} \%$. This unit is enhanced in $\mathrm{Fe}$, Ti and $\mathrm{Ca}$ (Fig. 3), which corresponds to the elemental composition of the sandstone clast samples (Table 4) and may indicate that the glacier advanced over a sandstone-rich band within the pelitic metasedimentary bedrock. This may also explain the decrease in $\mathrm{Rb} / \mathrm{Sr}$ ratios. Despite the erosive contact at the base of Unit B, the excellent preservation of laminations, with no evidence of deformation, suggests that ice did not advance across the lake basin at that time. Whilst it is possible that sediment can be preserved following overrunning by cold-based ice, as seen in some High-Arctic lake settings (McFarlin et al.
2018), we see little evidence for this in the Madsen Lake catchment, and it is likely that during the deposition of Unit B, the ice margin lay around Moraine Position 2. It is not possible to ascertain whether Unit B was deposited during glacial advance, stillstand or recession, but this unit provides clear evidence for an enhanced period of glacial activity and sediment erosion and downstream transfer. The timing of this phase of glacial activity, during the Dark Ages Cooling Period, is consistent with evidence from other Arctic proglacial lake and moraine records, which indicate an advance at approximately $1000 \mathrm{cal}$. a BP, prior to the LIA (Jomelli et al. 2016; Van der Bilt et al. 2018).

Following the deposition of Unit B, the reduction in minerogenic sediment content and elemental values, together with a rise in TOC concentrations and the rich bryophyte content of Unit $\mathrm{C}$, indicate that ice has receded and environmental conditions around the lake have returned to those recorded in Bed A. This part of the succession is not directly dated, but the 20 -cm-thick unit suggests a prolonged period of ice-free conditions in the lower catchment, rather than a temporary quiescent phase during dynamic ice retreat. Our age-depth model suggests that these conditions lasted from $c$. 1190 to $940 \mathrm{cal}$. a BP. It is likely that the ice margins were located close to their present-day positions on the flanks of the plateau, or at higher elevations, but additional modelling of palaeoglaciological behaviour is required to resolve this further.

A second phase of enhanced glacial activity is recorded from 940 to 825 cal. a BP (modelled age; Unit D), indicated by renewed minerogenic sediment delivery, reduced $\mathrm{TOC} \%$ and $\mathrm{Si} / \mathrm{Ti}$ ratio, and increased $\mathrm{DBD}$ and MS values. We interpret this as a re-advance of the glacier towards the lake basin.

This is followed by a short period of reduced minerogenic sediment input (Unit E1), which does not correspond to an increase in TOC $\%$ or the Si/Tiratio, unlike the conditions recorded in Units A and C. Low $\mathrm{Mn} / \mathrm{Fe}$ ratios 
indicate anoxic bottom conditions and thus reduced lake water circulation, while shifts in $\mathrm{Ca}$ and $\mathrm{Rb} / \mathrm{Sr}$ indicate reduced chemical weathering. We interpret this as most likely due to a reduction in meltwater input and associated generation of bottom flows in the lake, possibly as a result of glacier retreat.

A third phase of enhanced glacial activity is recorded by Unit E2, close to the onset of the LIA (modelled age $c$. $700-550$ cal. a BP). High DBD, MS, Mn/Fe and GSD 90 values, coupled with low TOC and $\mathrm{Rb} / \mathrm{Sr}$ ratios are indicative of enhanced detrital sediment inputs, associated chemical weathering, and increased lake water circulation during this period. Unlike Units B and D, this phase is not visible in the sedimentary record. However, using XRD cluster analysis it is possible to identify similarities between the mineralogical signature of this unit and the preceding glacially derived sediments (Units B and D). This unit may therefore represent a more muted or short-lived cold oscillation involving ice re-advance that has not been clearly recorded in the sedimentary characteristics. Alternatively, it may mark a phase of enhanced meltwater input due to glacier retreat, but its modelled age at the onset of the LIA is more consistent with a period of glacier growth. This highlights that in the High Arctic, even relatively low amplitude geochemical changes can be indicative of pronounced environmental change and emphasizes the value of detailed geochemical measurements to reliably reconstruct glacial history.

Unit E3, at the top of the succession, displays fluctuating mineral composition and consistent PCA scores. TOC $\%$ remains low until the top $2 \mathrm{~cm}$ of the unit, as do $\mathrm{Rb} / \mathrm{Sr}$ ratios. Laminations remain intact, but it cannot be ruled out that this part of the core has been truncated. If the core is intact, the age-depth model indicates that this unit coincides with the coldest part of the LIA, in which case the very low accumulation rate $\left(0.28 \mathrm{~mm} \mathrm{a}^{-1}\right)$ may indicate a period of prolonged or perennial lake ice cover, and therefore reduced or non-deposition of sediment (Levy et al. 2014).

\section{Sediment geochemistry and mineralogy}

Examination of the relationships between sediment characteristics, TOC, elemental and mineralogical composition (Fig. 3) provides detailed insights into glacier behaviour and downstream sediment transfer. The phases of glacigenic sediment deposition are characterized by high DBD and MS, low TOC, and GSD90 values that are indicative of elevated clay content. Increased $\mathrm{Ti}$ and $\mathrm{Ca}$ content seen in the Madsen Lake succession have also been used elsewhere as indicators of enhanced glacial erosion of catchment bedrock (Bakke et al. 2009; de Wet et al. 2018). The Ti-TOC biplot (Fig. 5C) demonstrates that sediments with higher TOC concentrations are relatively depleted in $\mathrm{Ti}$, while glacially derived sediments contain negligible organic carbon.
During glacial depositional phases, low TOC values and Si/Ti ratios (Fig. 3) suggest a lake environment with high clastic sediment input and thus limited biological activity. This is probably due to an increase in the relative abundance of the finest sediment size fractions $(<50 \mu \mathrm{m})$, evidenced by the low GSD90 scores, which have been shown to inhibit sunlight penetration of the water column, and greatly reduce biological processes (Slemmons et al. 2017). During these phases, high Ti/Al ratios (Fig. 5B) point to an increase in detrital sediment inputs. Low $\mathrm{Rb} / \mathrm{Sr}$ ratios demonstrate that $\mathrm{Rb}$ is not profoundly influenced by glacier activity in the Madsen Lake catchment, even though in other catchments it has been associated with enhanced chemical weathering and detrital clays (Jin et al. 2001; Vasskog et al. 2011). Instead, Sr levels increase during glacial advance phases, and its covariance with $\mathrm{Ca}$ (Fig. 5A) indicates the simultaneous glacially driven bedrock weathering of these elements, and delivery to the lake downstream. This is consistent with monitored observations from Glacier de Tsanfleuron, Switzerland, where $\mathrm{Sr}$ and $\mathrm{Ca}$ concentrations become progressively concentrated in downstream meltwater systems (Fairchild et al. 1994). Glacially comminuted Ca-rich grains are easily dissolved and transported by low temperature meltwater river systems (Fairchild et al. 1994, 1999; Anderson et al. 2000; Adamson et al. 2014), which may also partly explain their elevated concentrations in Madsen Lake during periods of glacier activity. MS values increase abruptly at the onset of glacigenic sediment depositional phases (Units B and D) and remain elevated but highly variable in the uppermost part of the succession (Units E1-E3). Together with fluctuating DBD values this may reflect short-term variations in glacier activity, meltwater flows, lake ice cover, and therefore sediment source and delivery into the lake basin. This highlights the intricacy of the sedimentary signature in this part of the succession and the complex ways in which glacier behaviour is recorded in lake sediments.

\section{Drivers of Late Holocene Arctic glacier behaviour}

The first phase of glacial activity recorded in Madsen Lake (Unit B) is consistent with data from other parts of Greenland, which suggest a phase of enhanced glacier activity at $c .1000$ cal. a BP, prior to the LIA, and broadly coincident with the Dark Ages Cold Period (e.g. Ljungqvist 2010 and Table 1). Diatom assemblages from Raffles Sø, Scoresby Sund, suggest the onset of colder conditions and lake ice growth at $1800 \mathrm{cal}$. a BP (Cremer et al. 2001). This precedes the glacial signal recorded in Madsen Lake, but could represent the onset of Late Holocene climatic deterioration in east Greenland. In southeast Greenland, ${ }^{10} \mathrm{Be}$ ages suggest that the southernmost part of the GrIS reached a maximum at 1510 a (Winsor et al. 2014). Lake sediments proximal to the Kulusuk glacier in southeast Greenland record a major advance at $1300 \mathrm{cal}$. a BP (Balascio et al. 2015), and sediments from the nearby 

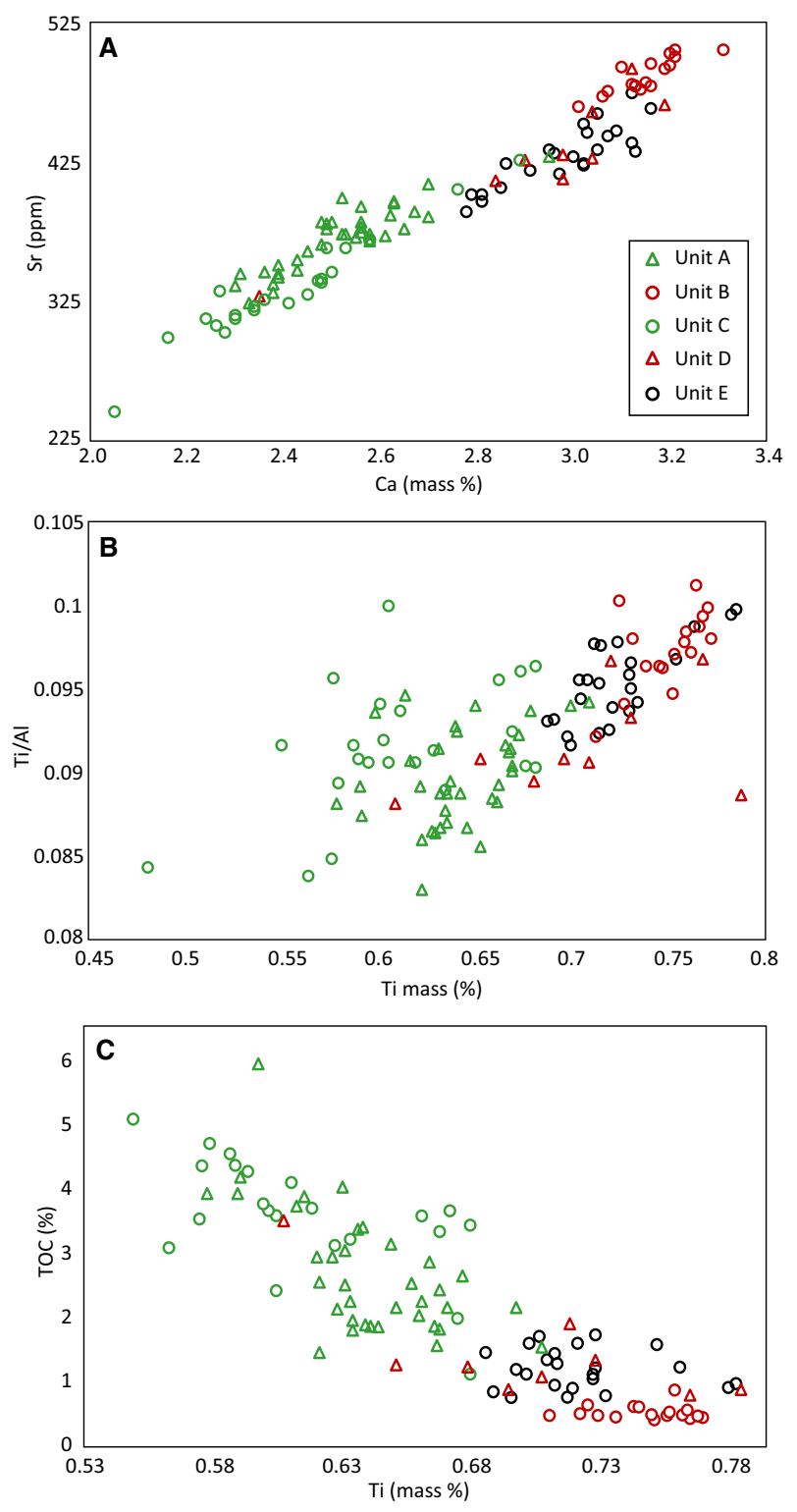

Fig. 5. A. Scatterplot of $\mathrm{Sr}(\mathrm{ppm})$ vs. $\mathrm{Ca}$ (mass \%). More organic units, which represent reduced glacial input from Slettebreen are in green (Units A and C). Minerogenic units, which represent enhanced glacial activity are in red (Units B and D). Unit E, which contains a complex minerogenic signal is in black. B. Relationship between Ti/Al and Ti (mass \%). Sedimentary unit symbols follow part A. C. Relationship between TOC (\%) and Ti (mass \%). Sedimentary unit symbols follow part A (For interpretation of the references to colour in this figure legend, the reader is referred to the web version of this article).

Ymer Lake, Ammassalik, also record glacier regrowth at $c$. 1200 cal. a BP (Van der Bilt et al. 2018).

The second glacial advance recorded in Madsen Lake (Unit D: c. 940-825 cal. a BP) is synchronous with evidence of glacial advance in Greenland and further afield (Fig. 6H) during the Medieval Climate Anomaly (MCA). Lake sediments in east Greenland show that Istorvet ice cap reached its maximum at $c .865$ cal. a BP, remaining at this position until at least 355 cal. a BP
(Lowell et al. 2013; Lusas et al. 2017). Surface exposure ages from moraines on Scoresby Sund have dated recent advances of the Bregne ice cap to 740 a (Levy et al. 2014), and to 780-310 a in Gurreholm Dal (Kelly et al. 2008). In West Greenland and Baffin Island, moraine successions recently dated with both ${ }^{10} \mathrm{Be}$ and ${ }^{36} \mathrm{Cl}$ have provided compelling evidence for glacier advances at 975, 885 and 800 a (Young et al. 2015; Jomelli et al. 2016). As highlighted by Lowell et al. (2013), these pre-LIA advances are not unique to Greenland - records from Switzerland (Holzhauser et al. 2005), Canada (Luckman 1995) and Alaska (Wiles et al. 2008) also demonstrate pre-LIA and LIA glacier advances.

The continuation of low biological activity after this second advance indicates a prolonged climate downturn, similar to that recorded at Istorvet ice cap to the south (Lowell et al. 2013; Lusas et al. 2017). A third phase of enhanced glacial activity after $700 \mathrm{a}$ in the Madsen Lake catchment is evident only in the geochemical record, and not the visual stratigraphy, and probably reflects changes in regional climate associated with onset of the LIA. As stated above, the highest part of the succession, close to the sediment-water interface, may be incomplete, but it is not possible to test this due to chronological constraints. The sediments are horizontally laminated and undisturbed, and if considered an intact record, may represent a period of inferred extensive ice cover on the lake, and/or cold conditions, impeding sediment delivery to the lake basin. These conditions - the coldest recorded in the Madsen Lake succession - are concordant with widespread regional evidence of cooling into the LIA.

Over the last 2000 years, regional variations in Arctic climate (PAGES 2k Consortium 2013) have been manifest as complex spatial patterns of ice advance and retreat, and regional climate has been modulated by local factors (Lusas et al. 2017). Arctic glacier behaviour is driven by summer temperature (during ablation season), which accounts for up to $90 \%$ of interannual mass balance variations (Koerner 2005). Significant increases in precipitation at around $1000 \mathrm{cal}$. a BP could have helped to force glacier advance in Zackenberg; however, ice-core records suggest little variation in accumulation rates over the last 1800 years (Fig. 6E; Andersen et al. 2006). The Late Holocene advances recorded at Madsen Lake are coincident with reduced Arctic temperatures $\left(0.4{ }^{\circ} \mathrm{C}\right.$ below present), recorded in high-resolution proxy records (Fig. 6B, C; PAGES 2k Consortium 2013) and reconstructed temperature decreases at NGRIP (up to $2.5^{\circ} \mathrm{C}$ cooling) (Fig. 6D), suggesting large-scale climatic cooling. At present, the mechanisms responsible for pre-LIA glacier expansions in Greenland (Fig. $6 \mathrm{H}$ ) are disputed. Reductions in solar irradiance and a period of persistent tropical volcanism, thought to have caused the onset of the LIA (Miller et al. 2012; Swingedouw et al. 2015), have been invoked as forcing mechanisms for some Greenlandic glacial advances (Young et al. 2015; Jomelli et al. 2016). However, the 

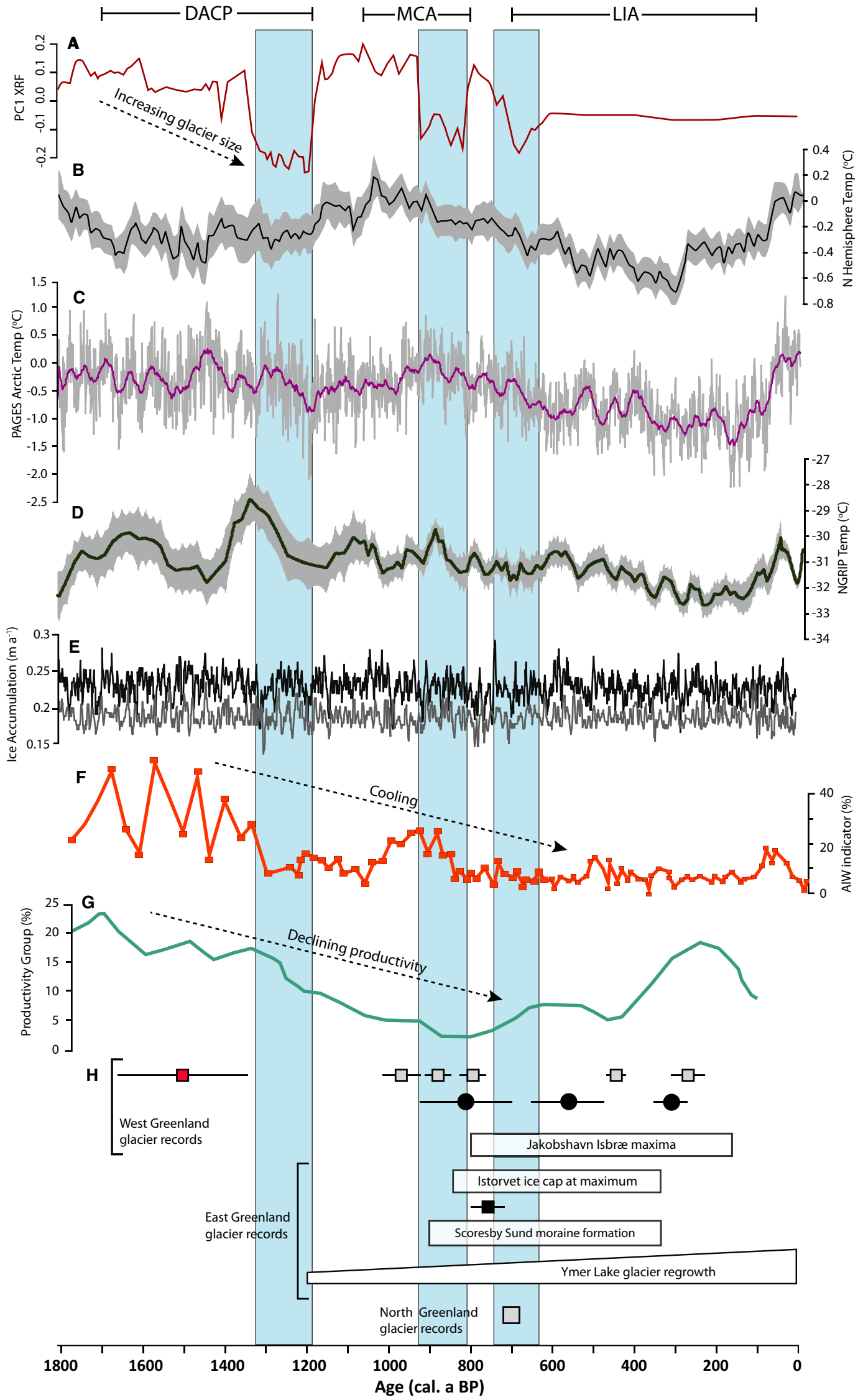
Fig. 6. A. PC1 axis from the Madsen Lake record. B. Extra-tropical Northern Hemisphere decadal mean temperature relative to the 1961-1990 instrumental temperature, with 2 standard deviation error bars (grey shading). C. Arctic reconstructed temperature (PAGES 2k Network 2013). D. NGRIP reconstructed temperature from argon and nitrogen isotopes, with $2 \sigma$ error bands (grey shading)(Kobashi et al. 2017). E. Ice accumulation records from GRIP (black line) and NGRIP (grey line) showing very limited variations in ice accumulation across the last 1800 years (Andersen et al., 2006). F. Chilled Atlantic Water (AIW) foraminiferal assemblage group $\%$ from East Greenland Shelf (Perner et al. 2015). G. Foraminiferal assemblage productivity group \% (Perner et al. 2016). H. Glacier records from West Greenland: Kiagtut Sermia, southwest Greenland (red square: Winsor et al. 2014), Uigordleq and Baffin Island (grey squares: Young et al. 2015), Disko Island (black circles: Jomelli et al. 2016), Jakobshavn Isbræ (Lloyd 2006; Briner et al. 2011; Young et al. 2011); East Greenland: Istorvet ice cap (Lowell et al. 2013; Lusas et al. 2017), Scoresby Sund (Kelly et al. 2008), Bregne ice cap (black square: Levy et al. 2014), Ymer Lake, Ammassalik (Van der Bilt et al. 2018); and North Greenland (Bennike 2002). Specific climatic periods/events are shown at the top: Dark Ages Cold Period (DACP), Medieval Climate Anomaly (MCA) and Little Ice Age (LIA) (after Kolling et al. 2017). Periods of glacier advance inferred from PCA axis 1 are shown in vertical blue bars (For interpretation of the references to colour in this figure legend, the reader is referred to the web version of this article).

Slettebreen glacier advances occurred before the periods of reduced irradiance ( 900 cal. a BP) and volcanic activity (650 cal. a BP). Sediments from the East Greenland shelf have provided evidence for strengthening of cold polar waters and reductions in primary productivity from 1400 cal. a BP (Fig. 6F, G; Perner et al. 2015, 2016), and periods of enhanced sea ice in Prinz Josef Fjord, $\sim 150 \mathrm{~km}$ southwest of Madsen Lake (Kolling et al. 2017) throughout the Neoglacial. Van der Bilt et al. (2018) propose a mechanism by which weakening of the Sub Polar Gyre caused a change in North Atlantic Oscillation phasing, leading to climatic conditions conducive for glacier growth in Greenland, but not in western Europe. However, at present, the direct climatic forcing of pre-LIA glacier expansion remains unsolved. Results from Madsen Lake are part of a growing body of evidence for pre-LIA glacier advances in this part of the Arctic. Together this suggests that the palaeo-behaviour of Slettebreen is not dependent on local conditions, but instead part of a regional response. Our results highlight the importance of high-resolution sediment geochemical analysis, to identify rapid glacier advance-retreat phases, where geomorphological and stratigraphical records are fragmentary.

\section{Conclusions}

Detailed geochemical analysis of proglacial lake sediments close to Zackenberg, northeast Greenland, reveals three phases of enhanced glacial activity, including two distinct episodes of ice advance, in the last 2000 years. The first two phases occurred prior to the LIA (c. 1320800 cal. a BP) and are close in age to the Dark Ages Cold Period and the MCA. The third phase $(c .700$ cal. a BP), representing a short-lived glacier oscillation, is associated with the onset of the LIA. This is consistent with recent evidence of a period of Arctic glacier advance prior to the LIA.

The sub-millennial glacier fluctuations identified in the Madsen Lake succession are not preserved in the moraine record. Significantly, high-resolution, coupled $\mathrm{XRF}$ and XRD analysis has allowed us to identify a phase of glacial sediment input that cannot be distinguished by sedimentology alone. This highlights the importance of detailed geochemical analysis for recon- structing sub-millennial, Arctic glacier behaviour. In regions where dating control is scarce, geochemical analysis can be used to examine variations in glacially driven sediment erosion and deposition patterns and develop meaningful interpretations in the context of regional climate proxy records.

Acknowledgements. - We would like to thank two anonymous reviewers for their comments on an earlier version of the manuscript. DEMs were provided by the Polar Geospatial Center under NSF OPP awards 1043681, 1559691 and 1542736. Fieldwork was made possible through EU-INTERACT Funding (grant agreement no. 262693) under the European Community's Seventh Framework Programme, Manchester Metropolitan University research funding, and Liverpool John Moores' ECR Fellowship funding. Thanks to Gary Miller for his assistance with XRD analysis at Manchester Metropolitan University. Thanks to the Geography Laboratories at the University of Manchester for their support with XRF, grain size, and magnetic susceptibility analysis.

\section{References}

Abermann, J., van As, D., Wacker, S. \& Langley, K. 2017: Mountain glaciers vs Ice sheet in Greenland: learning from a new monitoring site in West Greenland. EGU General Assembly Conference Abstracts 19, Abstract no. 9445.

Adamson, K. R., Woodward, J. C. \& Hughes, P. D. 2014: Glacial crushing of limestone and the production of carbonate-rich silts in a Pleistocene glaciofluvial system: a potential source of loess in Southern Europe. Geografiska Annaler: Series A, Physical Geography 96, 339-356.

Andersen, K. K., Ditlevsen, P. D., Rasmussen, S. O., Clausen, H. B., Vinther, B. M., Johnsen, S. J. \& Steffensen, J. P. 2006: Retrieving a common accumulation record from Greenland ice cores for the past 1800 years. Journal of Geophysical Research: Atmospheres 111, D15106, https://doi.org/10.1029/2005jd006765.

Anderson, S. P., Drever, J. I., Frost, C. D. \& Holden, P. 2000: Chemical weathering in the foreland of a retreating glacier. Geochimica et Cosmochimica Acta 64, 1173-1189.

Axford, Y., Levy, L. B., Kelly, M. A., Francis, D. R., Hall, B. L., Langdon, P. G. \& Lowell, T. V. 2017: Timing and magnitude of early to middle Holocene warming in East Greenland inferred from chironomids. Boreas 46, 678-687.

Bakke, J., Lie, Ø., Heegaard, E., Dokken, T., Haug, G. H., Birks, H. H., Dulski, P. \& Nilsen, T. 2009: Rapid oceanic and atmospheric changes during the Younger Dryas cold period. Nature Geoscience 2, 202-205.

Bakke, J., Trachsel, M., Kvisvik, B. C., Nesje, A. \& Lyså, A. 2013: Numerical analyses of a multi-proxy data set from a distal glacier-fed lake, Sørsendalsvatn, western Norway. Quaternary Science Reviews 73, 182-195.

Balascio, N. L., D’Andrea, W. J. \& Bradley, R. S. 2015: Glacier response to North Atlantic climate variability during the Holocene. Climate of the Past 11, 1587-1598. 
Bennike, O. 2002: Late Quaternary history of Washington Land, North Greenland. Boreas 31, 260-272.

Bennike, O. \& Wagner, B. 2012: Deglaciation chronology, sea-level changes and environmental changes from Holocene lake sediments of Germania Havn Sø, Sabine Ø, northeast Greenland. Quaternary Research 78, 103-109.

Bennike, O. \& Weidick, A. 2001: Late Quaternary history around Nioghalvfjerdsfjorden and Jøkelbugten, North-East Greenland. Boreas 30, 205-227.

Bjørk, A. A., Kjær, K. H., Korsgaard, N. J., Khan, S. A., Kjeldsen, K. K., Andresen, C. S., Box, J. E., Larsen, N. K. \& Funder, S. 2012: An aerial view of 80 years of climate-related glacier fluctuations in southeast Greenland. Nature Geoscience 5, 427-432.

Blaauw, M. \& Christen, J. A. 2011: Flexible paleoclimate age-depth models using an autoregressive gamma process. Bayesian Analysis 6 , 457-474.

Bliss, L. C. 1997: Arctic ecosystems of North America. In Wielgolaski, F. E. (ed.): Polar and Alpine Tundra, 551-683. Elsevier, Amsterdam.

Bolch, T., Sandberg Sørensen, L., Simonsen, S. B., Mölg, N., Machguth, H., Rastner, P. \& Paul, F. 2013: Mass loss of Greenland's glaciers and ice caps 2003-2008 revealed from ICESat laser altimetry data. Geophysical Research Letters 40, 875-881.

Böning, C. W., Behrens, E., Biastoch, A., Getzlaff, K. \& Bamber, J. L. 2016: Emerging impact of Greenland meltwater on deepwater formation in the North Atlantic Ocean. Nature Geoscience 9, 523527.

Bretz, J. H. 1935: Physiographic studies in east Greenland. American Geographical Society 18, 159-267.

Briner, J. P., Stewart, H. A. M., Young, N. E., Philipps, W. \& Losee, S. 2010: Using proglacial-threshold lakes to constrain fluctuations of the Jakobshavn Isbrae ice margin, western Greenland, during the Holocene. Quaternary Science Reviews 29, 3861-3874.

Briner, J. P., Young, N. E., Thomas, E. K., Stewart, H. A. M., Losee, S. \& Truex, S. 2011: Varve and radiocarbon dating support the rapid advance of Jakobshavn Isbrae during the Little Ice Age. Quaternary Science Reviews 30, 2476-2486.

Carr, J. R., Stokes, C. R. \& Vieli, A. 2013: Recent progress in understanding marine-terminating Arctic outlet glacier response to climatic and oceanic forcing: Twenty years of rapid change. Progress in Physical Geography 37, 436-467.

Carrivick, J. L. \& Tweed, F. S. 2013: Proglacial lakes: Character, behaviour and geological importance. Quaternary Science Reviews $78,34-52$

Christiansen, H. H. \& Humlum, O. 1993: Glacial history and periglacial landforms of the Zackenberg area, northeast Greenland: preliminary results. Geografisk Tidsskrift, Danish Journal of Geography 93, 19-29.

Christiansen, H. H., Sigsgaard, C., Humlum, O., Rasch, M. \& Hansen, B. U. 2008: Permafrost and periglacial geomorphology at Zackenberg. Advances in Ecological Research 40, 151-174.

Christoffersen, K. S., Amsinck, S. L., Landkildehus, F., Lauridsen, T. L. \& Jeppesen, E. 2008: Lake flora and fauna in relation to ice-melt, water temperature and chemistry at Zackenberg. Advances in Ecological Research 40, 371-389.

Cremer, H., Wagner, B., Melles, M. \& Hubberten, H. W. 2001: The postglacial environmental development of Raffles Sø, East Greenland: inferences from a 10,000 year diatom record. Journal of Paleolimnology 26, 67-87.

Dearing, J. 1999: Magnetic susceptibility. In Walden, J., Oldfield, F., Smith, J. P. (eds.): Environmental Magnetism: A Practical Guide. Technical Guide No. 6, 35-62, Quaternary Research Association, London.

Evans, J., Ó Cofaigh, C., Dowdeswell, J. A. \& Wadhams, P. 2009: Marine geophysical evidence for former expansion and flow of the Greenland Ice Sheet across the north-east Greenland continental shelf. Journal of Quaternary Science 24, 279-293.

Fairchild, I. J., Bradby, L. \& Spiro, B. 1994: Reactive carbonate in glacial systems: a preliminary synthesis of its creation, dissolution and reincarnation. In Deynoux, M., Miller, J. M. G., Domack, E. W., Eyles, N., Fairchild, I. J. \& Young, G. M. (eds.): Earth's Glacial Record - IGCP Project 260, 176-192. Cambridge University Press, Cambridge.
Fairchild, I. J., Killawee, J. A., Hubbard, B. \& Dreybrodt, W. 1999: Interactions of calcareous suspended sediment with glacial meltwater: a field test of dissolution behaviour. Chemical Geology 155, 243263

Filzmoser, P. \& Varmuza, K. 2017: Chemometrics: Multivariate Statistical Analysis in Chemometrics. $R$ package version 1.4.2. Available at: https://CRAN.R-project.org/package $=$ chemometrics.

Gilbert, G. L., Cable, S., Thiel, C., Christiansen, H. H. \& Elberling, B. 2017: Cryostratigraphy, sedimentology, and the late Quaternary evolution of the Zackenberg River delta, northeast Greenland. Cryosphere 11, 1265-1282.

Gjerde, M., Bakke, J., D’Andrea, W. J., Balascio, N. L., Bradley, R. S., Vasskog, K., Olafsdottir, S., Røthe, T. O., Perren, B. B. \& Hormes, A. 2017: Holocene multi-proxy environmental reconstruction from Lake Hakluytvatnet, Amsterdamøya Island Svalbard $\left(79.5^{\circ} \mathrm{N}\right)$. Quaternary Science Reviews 183, 164-176.

Hansen, B. U., Sigsgaard, C., Rasmussen, L., Cappelen, J., Hinkler, J., Mernild, S. H., Petersen, D., Tamstorf, M. P., Rasch, M. \& Hasholt, B. 2008: Present-day climate at Zackenberg. Advances in Ecological Research 40, 111-149.

Hansen, J., Topp-Jørgensen, E. \& Christensen, T. R. 2015: Zackenberg Ecological Research Operations 21st Annual Report. 96 pp. Aarhus University, DCE - Danish Centre for Environment and Energy.

Hobbie, J. E., Shaver, G. R., Rastetter, E. B., Cherry, J. E., Goetz, S. J., Guay, K. C., Gould, W. A. \& Kling, G. W. 2017: Ecosystem responses to climate change at a Low Arctic and a High Arctic long-term research site. Ambio 46, 160-173.

Holzhauser, H., Magny, M. \& Zumbuühl, H. J. 2005: Glacier and lakelevel variations in west-central Europe over the last 3500 years. The Holocene 15, 789-801.

Jacobsson, P., Hamilton, W. D., Cook, G., Crone, A., Dunbar, E., Kinch, H., Naysmith, P., Tripney, B. \& Xu, S. 2018: Refining the Hallstatt Plateau: short-term ${ }^{14} \mathrm{C}$ variability and small scale offsets in 50 consecutive single tree-rings from Southwest Scotland dendrodated to 510-460 BC. Radiocarbon 60, 219-237.

Jin, Z., Wang, S., Shen, J., Zhang, E., Li, F., Ji, J. \& Lu, X. 2001: Chemical weathering since the Little Ice Age recorded in lake sediments: a high-resolution proxy of past climates. Earth Surface Processes and Landforms 26, 775-782.

Jomelli, V., Lane, T., Favier, V., Masson-Delmotte, V., Swingedouw, D., Rinterknecht, V., Schimmelpfennig, I., Brunstein, D., Verfaillie, D., Adamson, K. \& Leanni, L. 2016: Paradoxical cold conditions during the medieval climate anomaly in the Western Arctic. Scientific Reports 6, 32984, https://doi.org/10.1038/srep32984.

Karlén, W. 1981: Lacustrine sediment studies-a technique to obtain a continuous record of Holocene glacier variations. Geografiska Annaler Series A-Physical Geography 63, 273-281.

Kelly, M. A. \& Lowell, T. V. 2009: Fluctuations of local glaciers in Greenland during latest Pleistocene and Holocene time. Quaternary Science Reviews 28, 2088-2106.

Kelly, M. A., Lowell, T. V., Hall, B. L., Schaefer, J. M., Finkel, R. C., Goehring, B. M., Alley, R. B. \& Denton, G. H. 2008: A 10Be chronology of lateglacial and Holocene mountain glaciation in the Scoresby Sund region, east Greenland: implications for seasonality during lateglacial time. Quaternary Science Reviews 27, 2273-2282

Klug, M., Bennike, O. \& Wagner, B. 2009a: Repeated short-term bioproductivity changes in a coastal lake on Store Koldewey, northeast Greenland: an indicator of varying sea-ice coverage? The Holocene 19, 653-663.

Klug, M., Schmidt, S., Bennike, O., Heiri, O., Melles, M. \& Wagner, B. 2009b: Lake sediments from store Koldewey, northeast Greenland, as archive of late Pleistocene and Holocene climatic and environmental changes. Boreas 38, 59-71.

Kobashi, T., Menviel, L., Jeltsch-Thömmes, A., Vinther, B. M., Box, J. E., Muscheler, R., Nakaegawa, T., Pfister, P. L., Döring, M., Leuenberger, M. \& Wanner, H. 2017: Volcanic influence on centennial to millennial Holocene Greenland temperature change. Scientific Reports 7, 1441. https://doi.org/10.1038/s41598.

Koerner, R. M. 2005: Mass balance of glaciers in the Queen Elizabeth Islands, Nunavut, Canada. Annals of Glaciology 42, 417-423. 
Kolling, H. M., Stein, R., Fahl, K., Perner, K. \& Moros, M. 2017: Shortterm variability in late Holocene sea ice cover on the East Greenland Shelf and its driving mechanisms. Palaeogeography, Palaeoclimatology, Palaeoecology 485, 336-350.

Lasher, G. E., Axford, Y., McFarlin, J. M., Kelly, M. A., Osterberg, E. C. \& Berkelhammer, M. B. 2017: Holocene temperatures and isotopes of precipitation in Northwest Greenland recorded in lacustrine organic materials. Quaternary Science Reviews 170, 45-55.

Leeman, A. \& Niessen, F. 1994: Holocene glacial activity and climate variations in the Swiss Alps: reconstructing a continuous record from proglacial lake sediments. The Holocene 4, 259-268.

Levy, L. B., Kelly, M. A., Lowell, T. V., Hall, B. L., Hempel, L. A., Honsaker, W. M., Lusas, A. R., Howley, J. A. \& Axford, Y. L. 2014: Holocene fluctuations of Bregne ice cap, Scoresby Sund, east Greenland: a proxy for climate along the Greenland Ice Sheet margin. Quaternary Science Reviews 92, 357-368.

Ljungqvist, F. C. 2010: A new reconstruction of temperature variability in the extra-tropical Northern Hemisphere during the last two millennia. Geografiska Annaler: Series A, Physical Geography 92, 339-351.

Lloyd, J. M. 2006: Late Holocene environmental change in Disko Bugt, west Greenland: interaction between climate, ocean circulation and Jakobshavn Isbræ. Boreas 35, 35-49.

Lowell, T. V., Hall, B. L., Kelly, M. A., Bennike, O., Lusas, A. R., Honsaker, W., Smith, C. A., Levy, L. B., Travis, S. \& Denton, G. H. 2013: Late Holocene expansion of Istorvet ice cap, Liverpool Land, east Greenland. Quaternary Science Reviews 63, 128-140.

Luckman, B. H. 1995: Calendar-dated, early 'Little Ice Age' glacier advance at Robson Glacier, British Columbia, Canada. The Holocene 5, 149-159.

Lund, M., Abermann, J. \& Skov, K. 2017: Environmental effects of a rare rain event in the high Arctic. EGU General Assembly Conference Abstracts 19, Abstract no. 9462.

Lusas, A. R., Hall, B. L., Lowell, T. V., Kelly, M. A., Bennike, O., Levy, L. B. \& Honsaker, W. 2017: Holocene climate and environmental history of East Greenland inferred from lake sediments. Journal of Paleolimnology 57, 321-341.

MacGregor, K. R., Riihimaki, C. A., Myrbo, A., Shapley, M. D. \& Jankowski, K. 2011: Geomorphic and climatic change over the past 12,900 yr at Swiftcurrent Lake, Glacier National Park, Montana, USA. Quaternary Research 75, 80-90.

Machguth, H., Rastner, P., Bolch, T., Mölg, N., Sørensen, L. S., Aðalgeirsdottir, G., Van Angelen, J. H., Van den Broeke, M. R. \& Fettweis, X. 2013: The future sea-level rise contribution of Greenland's glaciers and ice caps. Environmental Research Letters 8, 025005, https://doi.org/10.1088/17489326/8/2/025005.

Machguth, H., Thomsen, H. H., Weidick, A., Ahlstrøm, A. P., Abermann, J., Andersen, M. L., Andersen, S. B., Bjørk, A. A., Box, J. E., Braithwaite, R. J. \& Bøggild, C. E. 2016: Greenland surface mass-balance observations from the ice-sheet ablation area and local glaciers. Journal of Glaciology 62, 861-887.

McFarlin, J. M., Axford, Y., Osburn, M. R., Kelly, M. A., Osterberg, E. C. \& Farnsworth, L. B. 2018: Pronounced summer warming in northwest Greenland during the Holocene and Last Interglacial. Proceedings of the National Academy of Sciences of the United States of America 115, 6357-6362.

Meier, M. F. \& Post, A. 1969: What are glacier surges? Canadian Journal of Earth Sciences 6, 807-817.

Melles, M., Brigham-Grette, J., Minyuk, P. S., Nowaczyk, N. R., Wennrich, V., DeConto, R. M., Anderson, P. M., Andreev, A. A., Coletti, A., Cook, T. L. \& Haltia-Hovi, E. 2012: 2.8 million years of Arctic climate change from Lake El'gygytgyn, NE Russia. Science 337, 315-320

Miller, G. H., Geirsdóttir, Á., Zhong, Y., Larsen, D. J., Otto-Bliesner, B. L., Holland, M. M., Bailey, D. A., Refsnider, K. A., Lehman, S. J., Southon, J. R. \& Anderson, C. 2012: Abrupt onset of the Little Ice Age triggered by volcanism and sustained by sea-ice/ocean feedbacks. Geophysical Research Letters 39, L02708, https://doi.org/10. 1029/2011gl050168.

Moon, T., Joughin, I., Smith, B., Broeke, M. R., Berg, W. J., Noël, B. \& Usher, M. 2014: Distinct patterns of seasonal Greenland glacier velocity. Geophysical Research Letters 41, 7209-7216.
Naeher, S., Gilli, A., North, R. P., Hamann, Y. \& Schubert, C. J. 2013: Tracing bottom water oxygenation with sedimentary $\mathrm{Mn} / \mathrm{Fe}$ ratios in Lake Zurich, Switzerland. Chemical Geology 352, 125-133.

Noël, B., van de Berg, W. J., Wessem, V., Melchior, J., Van Meijgaard, E., Van As, D., Lenaerts, J., Lhermitte, S., Munneke, P. K., Smeets, C. J. P. \& Van Ulft, L. H. 2018: Modelling the climate and surface mass balance of polar ice sheets using RACMO2-Part 1: Greenland (19582016). Cryosphere 12, 811-831.

Ó Cofaigh, C., Dowdeswell, J. A., Evans, J., Kenyon, N. H., Taylor, J., Mienert, J. \& Wilken, M. 2004: Timing and significance of glacially influenced mass-wasting in the submarine channels of the Greenland Basin. Marine Geology 207, 39-54.

PAGES 2k Consortium 2013: Continental-scale temperature variability during the last two millennia. Nature Geoscience 6, 339-346.

Palmer, A., Rose, J., Lowe, J. J. \& MacLeod, A. 2010: Annually resolved events of Younger Dryas glaciation in Lochaber (Glen Roy and Glen Spean), Western Scottish Highlands. Journal of Quaternary Science $25,581-596$

Pedersen, M., Weng, W. L., Keulen, N. \& Kokfelt, T. 2013: A new seamless digital 1: 500000 scale geological map of Greenland. Geological Survey of Denmark and Greenland 28, 65-68.

Perner, K., Jennings, A. E., Moros, M., Andrews, J. T. \& Wacker, L. 2016: Interaction between warm Atlantic-sourced waters and the East Greenland Current in northern Denmark Strait $\left(68^{\circ} \mathrm{N}\right)$ during the last $10600 \mathrm{cal}$. a BP. Journal of Quaternary Science 31, 472-483.

Perner, K., Moros, M., Lloyd, J. M., Jansen, E. \& Stein, R. 2015: Mid to late Holocene strengthening of the East Greenland Current linked to warm subsurface Atlantic water. Quaternary Science Reviews 129, 296-307.

R Core Team. 2017: R: A language and environment for statistical computing. R Foundation for Statistical Computing, Vienna. Available at: https://www.R-project.org/.

Rastner, P., Bolch, T., Mölg, N., Machguth, H., Le Bris, R. \& Paul, F. 2012: The first complete inventory of the local glaciers and ice caps on Greenland. Cryosphere 6, 1483-1495.

Rea, B. R. 2009: Defining modern day Area-Altitude Balance Ratios (AABRs) and their use in glacier-climate reconstructions. Quaternary Science Reviews 28, 237-248.

Reimer, P. J., Bard, E., Bayliss, A., Beck, J. W., Blackwell, P. G., Ramsey, C. B., Buck, C. E., Cheng, H., Edwards, R. L., Friedrich, M., Grootes, P. M., Guilderson, T. P., Haflidason, H., Hajdas, I., Hatté, C., Heaton, T. J., Hoffmann, D. L., Hogg, A. G., Hughen, K. A., Kaiser, K. F., Kromer, B., Manning, S. W., Niu, M., Reimer, R. W., Richards, D. A., Scott, E. M., Southon, J. R., Staff, R. A., Turney, C. S. M. \& van der Plicht, J. 2013: IntCal13 and Marine13 radiocarbon age calibration curves 0-50,000 years cal BP. Radiocarbon 55, 1869-1887.

Schmidt, S., Wagner, B., Heiri, O., Klug, M., Bennike, O. \& Melles, M. 2011: Chironomids as indicators of the Holocene climatic and environmental history of two lakes in northeast Greenland. Boreas 40, 116-130.

Sharp, M., Lawson, W. \& Anderson, R. S. 1988: Tectonic processes in a surge-type glacier. Journal of Structural Geology 10, 499-515.

Slemmons, K. E., Medford, A., Hall, B. L., Stone, J. R., McGowan, S. Lowell, T., Kelly, M. \& Saros, J. E. 2017: Changes in glacial meltwater alter algal communities in lakes of Scoresby Sund, Renland, East Greenland throughout the Holocene: abrupt reorganizations began 1000 years before present. The Holocene 27, 929-940.

Striberger, J., Björck, S., Benediktsson, Í. Ö., Snowball, I., Uvo, C. B., Ingólfsson, Ó. \& Kjær, K. H. 2011: Climatic control of the surge periodicity of an Icelandic outlet glacier. Journal of Quaternary Science 26, 561-565.

Swingedouw, D., Ortega, P., Mignot, J., Guilyardi, E., MassonDelmotte, V., Butler, P. G., Khodri, M. \& Séférian, R. 2015: Bidecadal North Atlantic ocean circulation variability controlled by timing of volcanic eruptions. Nature Communications 6, 6545, https://doi.org/10.1038/ncomms 7545 .

Troels-Smith, J. 1955: Characterization of Unconsolidated Sediments. Geological Survey of Denmark IV Series, 3.

Van der Bilt, W., Rea, B., Spagnolo, M., Roerdink, D., Jørgensen, S. \& Bakke, J. 2018: Novel sedimentological fingerprints link shifting depositional processes to Holocene climate transitions in East Greenland. Global and Planetary Change 164, 52-64. 
Vasskog, K., Nesje, A., Støren, E. N., Waldmann, N., Chapron, E. \& Ariztegui, D. 2011: A Holocene record of snow-avalanche and flood activity reconstructed from a lacustrine sedimentary sequence in Oldevatnet, western Norway. The Holocene 21, 597-614.

Vieli, A., Lane, T. \& Adamson, K. 2017: Long-term evolution of a small ice cap in Greenland: a dynamic perspective from numerical flow modelling. EGU Geophysical Research Abstracts 19, Abstract no. 12149 .

Wagner, B., Melles, M., Hahne, J., Niessen, F. \& Hubberten, H. W. 2000: Holocene climate history of Geographical Society Ø, East Greenland - evidence from lake sediments. Palaeogeography, Palaeoclimatology, Palaeoecology 160, 45-68.

Weidick, A. 1968: Observations on some Holocene glacier fluctuations in west Greenland. Meddelelser om Grønland 165, 1-202.

Weidick, A., Bennike, O., Citterio, M. \& Nørgaard-Pedersen, N. 2012: Neoglacial and historical glacier changes around Kangersuneq fjord in southern West Greenland. Geological Survey of Denmark and Greenland 27, 1-68.

de Wet, G. A., Balascio, N. L., D’Andrea, W. J., Bakke, J., Bradley, R. S. \& Perren, B. 2018: Holocene glacier activity reconstructed from proglacial lake Gjøavatnet on Amsterdamøya, NW Svalbard. Quaternary Science Reviews 183, 188-203.

Wiles, G. C., Barclay, D. J., Calkin, P. E. \& Lowell, T. V. 2008: Century to millennial-scale temperature variations for the last two thousand years indicated from glacial geologic records of Southern Alaska. Global and Planetary Change 60, 115-125.

Winsor, K., Carlson, A. E. \& Rood, D. H. 2014: 10Be dating of the Narsarsuaq moraine in southernmost Greenland: evidence for a lateHolocene ice advance exceeding the Little Ice Age maximum. Quaternary Science Reviews 98, 135-143.

Wouters, B., Noël, B., Moholdt, G., Ligtenberg, S. \& van den Broeke, M. 2017: Mass loss of the Greenland peripheral glaciers and ice caps from satellite altimetry. EGU General Assembly Conference Abstracts 19, Abstract no. 9829.

Young, N. E., Briner, J. P., Stewart, H. A., Axford, Y., Csatho, B., Rood, D. H. \& Finkel, R. C. 2011: Response of Jakobshavn Isbræ, Greenland, to Holocene climate change. Geology 39, 131-134.

Young, N. E., Schweinsberg, A. D., Briner, J. P. \& Schaefer, J. M. 2015: Glacier maxima in Baffin Bay during the Medieval Warm Period coeval with Norse settlement. Science Advances 1, 1500806, https://d oi.org/10.1126/sciadv. 1500806

Zillén, L., Snowball, I., Sandgren, P. \& Stanton, T. 2003: Occurrence of varved lake sediment sequences in Varmland, west central Sweden: lake characteristics, varve chronology and AMS radiocarbon dating. Boreas 32, 612-626.

Zolitschka, B., Francus, P., Ojala, A. E. \& Schimmelmann, A. 2015: Varves in lake sediments - a review. Quaternary Science Reviews 117, 1-41. 